\author{
Dorota Szułczyńska, Ph.D.a)* \\ a) Scientific and Research Centre for Fire Protection - National Research Institute / Centrum Naukowo-Badawcze Ochrony \\ Przeciwpożarowej - Państwowy Instytut Badawczy \\ *Corresponding author / Autor korespondencyjny: dszulczynska@cnbop.pl
}

\title{
Determinants of the Perception of Asbestos
}

\section{Determinanty postrzegania azbestu}

\section{ABSTRACT}

Aim: The purpose of the article is to provide general information about the properties, application, legal aspects and methods of asbestos disposal. In addition, studies on the harmfulness of asbestos impact on the incidence of asbestos-related diseases among people are presented on the example of asbestosis in Poland. The threats that asbestos may cause during rescue and firefighting operations are discussed.

Introduction: Asbestos has been used in a variety of ways since ancient times. It gained popularity in the mid-twentieth century, when it began to be used in many building materials. It has become popular because of its unique properties. However, after 1990 there was a drastic change in the approach to the use of asbestos and asbestos products. Asbestos has been banned in 55 countries, including the EU, due to its harmfulness to human health. In Poland, the use and production of asbestos was banned in 1997, and in 2009 the "Asbestos Removal Programme" was introduced, which shows that by 2032 asbestos-containing products should be removed from Poland.

Although asbestos has been widely used for many years, safe commercial methods of asbestos disposal have not been developed yet.

In the world, many scientific studies are carried out to develop a method for processing and neutralising asbestos products. The research is aimed at developing modern and ecological methods for dealing with asbestos-containing waste.

Methodology: The article has been compiled on the basis of a review of selected literature on the subject matter covered.

Conclusions: The analysis of the subject allows a statement that both in Poland and in the world the problem of the disposal of asbestos products, which were widely applied in the 20th century, is large. It is necessary to develop safe, environmentally friendly and cost-effective technologies to reduce asbestos waste in the environment to be utilised on an industrial scale.

Every effort should be made to provide proper training for firefighters, who may be exposed to inhaling asbestos fibres during rescue and firefighting operations on collapsed or burning buildings.

Keywords: asbestos, waste neutralisation, utilisation of hazardous materials

Type of article: review article

Received: 09.04.2019; Reviewed: 27.08.2019; Accepted: 03.09.2019;

Author's ORCID ID: 0000-0001-8003-8452

Please cite as: SFT Vol. 53 Issue 1, 2019, pp. 144-161, https://doi.org/10.12845/sft.53.1.2019.9;

This is an open access article under the CC BY-SA 4.0 license (https://creativecommons.org/licenses/by-sa/4.0/).

\section{ABSTRAKT}

Cel: Celem artykułu jest przedstawienie ogólnych informacji o właściwościach, zastosowaniu, aspektach prawnych oraz metodach unieszkodliwiania azbestu. Ponadto przedstawiono badania szkodliwości oddziaływania azbestu na zachorowalność ludzi na choroby azbestozależne na przykładzie zapadalności na pylicę azbestową w Polsce. Omówiono zagrożenia, jakie może powodować azbest w trakcie prowadzenia działań ratowniczo-gaśniczych. Wprowadzenie: Azbest był wykorzystywany w różnorodny sposób już od starożytności. Jego popularność wzrosła w połowie XX wieku, kiedy zaczął być stosowany w wielu materiałach budowlanych. Uznanie zyskał ze względu na swe unikalne właściwości. Natomiast po roku 1990 nastąpiła drastyczna zmiana w podejściu do stosowania azbestu i wyrobów azbestowych. Ze względu na szkodliwość dla zdrowia ludzi azbest został zakazany w 55 krajach, w tym w UE. W Polsce stosowanie i produkcja azbestu jest zabroniona od 1997 r, a w 2009 roku wprowadzono "Program usuwania azbestu”, który nakazuje do 2032 r. usunięcie z terytorium Polski wyrobów zawierających azbest.

Mimo, że materiał ten był przez wiele lat powszechnie stosowany, do tej pory nie udało się opracować komercyjnych i bezpiecznych metod jego unieszkodliwiania.

Na świecie realizowanych jest wiele prac naukowych mających na celu opracowanie metody przetwarza i unieszkodliwiania wyrobów azbestowych Realizowane prace naukowe mają na celu opracowanie nowoczesnych i ekologicznych metod postępowania z odpadami zawierającymi azbest. 
Metodologia: Artykuł został opracowany na podstawie przeglądu wybranej literatury z zakresu poruszanej tematyki.

Wnioski: Analiza tematu pozwala na stwierdzenie, że zarówno w Polsce, jak i na świecie unieszkodliwianie wyrobów azbestowych cieszących się szerokim zainteresowaniem w XX wieku stanowi nadal duży problem. Istnieje konieczność opracowywania technologii - bezpiecznych, ekologicznych i opłacalnych do stosowania w skali przemysłowej - pozwalających na zmniejszenie odpadów azbestowych w środowisku .

Należy dołożyć wszelkich starań, aby zapewnić odpowiednie przeszkolenie strażaków, którzy podczas działań ratowniczo-gaśniczych przy zawalonych lub palących się budynkach mogą być narażeni na wdychanie włókien azbestu.

Słowa kluczowe: azbest, unieszkodliwianie odpadów, utylizacja materiałów niebezpiecznych

Typ artykułu: artykuł przeglądowy

Przyjęty: 09.04.2019; Zrecenzowany: 09.04.2019; Zatwierdzony: 03.09.2019;

Identyfikator ORCID autora: 0000-0001-8003-8452;

Autorzy wnieśli równy wkład merytoryczny w powstanie artykułu;

Proszę cytować: SFT Vol. 53 Issue 1, 2019, pp. 144-161, https://doi.org/10.12845/sft.51.3.2019.9;

Artykuł udostępniany na licencji CC BY-SA 4.0 (https://creativecommons.org/licenses/by-sa/4.0/).

\section{Introduction}

Between 1950 and 1990, asbestos was used as a component for manufacturing nearly 3000 products. Out of those products, the majority were originally intended for protecting human life and property against heat and fire hazards. Asbestos was used in many areas of the economy: ranging from the hotel industry, through military applications, to chemistry and construction. However, after 1990 the general perception of the use of asbestos and asbestos products changed dramatically.

Due to its properties detrimental to human life and health, asbestos has been banned in 55 countries, including EU Member States. In Poland, the use and manufacture of asbestos and products containing asbestos has been prohibited since 1997. The "Asbestos Removal Programme" collected data that showed that 8 million tonnes of asbestos-containing products should be removed from Poland by 2032 [1].

Although asbestos had been widely used for decades and was banned in the EU over 20 years ago, no safe commercial methods of its disposal have been yet developed. In addition, despite many years of raising general public's awareness of the harmful effects of asbestos, this subject still remains controversial.

Due to that, this article focuses on providing general information on the properties, use, legal conditions and methods for the disposal of asbestos and asbestos products. In addition, the article presents studies regarding the incidence of asbestosdependent diseases among people based on the example of asbestosis morbidity in Poland. Furthermore, the article discusses the potential asbestos-related risks borne by firefighters during firefighting operations.

\section{General considerations}

Asbestos is the trade name of a group of fibrous minerals [2] which in the chemical sense are hydrous silicates of various metals. Depending on the type of metals with which the silicates bond [3],

\section{Wprowadzenie}

W latach 1950-1990 azbest był używany do wytwarzania prawie 3000 produktów, z których większość miała za zadanie chronić życie i mienie od ciepła i ognia. Wykorzystywano go w wielu dziedzinach gospodarki: od hotelarstwa, poprzez technologie wojskowe, po przemysł chemiczny i budowlany. Natomiast po roku 1990 nastąpiła drastyczna zmiana w podejściu do stosowania azbestu i wyrobów azbestowych.

Ze względu na wykrytą szkodliwość dla zdrowia ludzi azbest został zakazany w 55 krajach, w tym w krajach członkowskich UE. W Polsce stosowanie i produkcja azbestu oraz wyrobów zawierających azbest jest zabroniona od 1997 r. Z danych zawartych W "Programie usuwania azbestu" wynika, że do 2032 r. z terytorium Polski należy usunąć $8 \mathrm{mln}$ ton wyrobów zawierających azbest [1].

Mimo że azbest był przez dziesięciolecia powszechnie stosowany, a przeszło 20 lat temu zakazano jego stosowania w UE, do tej pory nie udało się opracować komercyjnej i bezpiecznej metody jego unieszkodliwiania. Dodatkowo, mimo wielu lat uświadamiania społeczeństwa o szkodliwości azbestu, temat ten nadal wywołuje wiele kontrowersji.

Dlatego właśnie w niniejszym artykule skoncentrowano się na przedstawieniu ogólnych informacji o właściwościach, stosowaniu, uwarunkowaniach prawnych oraz metodach jego unieszkodliwiania. i wyrobów azbestowych. Ponadto przedstawiono badania zależności między szkodliwym działaniem azbestu a zapadalnością na choroby azbestozależne na przykładzie pylicy azbestowej w Polsce. Dodatkowo omówiono zagrożenia, których źródłem może być azbest podczas prowadzenia przez strażaków działań ratowniczogaśniczych.

\section{Informacje ogólne}

Azbest to nazwa handlowa grupy minerałów włóknistych [2], które pod względem chemicznym są uwodnionymi krzemianami różnych metali. Zależnie od tego, z jakim metalem krzemiany [3] 
they create several types of asbestos with different harmful effects on health [4]. Asbestos is a mineral of two classes: serpentines and amphiboles [5]. The first group includes chrysotile commonly referred to as white asbestos, while the second group includes amosite (brown asbestos), crocidolite (commonly called blue asbestos), anthophyllite, tremolite and actinolite [6-8].

Blue asbestos (crocidolite) is the most hazardous, while white asbestos (chrysotile) is the most widely used for commercial applications and constitutes approximately $90-95 \%$ of all asbestos products $[9,10]$, followed by blue and brown asbestos (amosite) [11]. Figure 1 presents the distribution of varieties of asbestos in the context of their use in industry. tworzą związek, wyróżnia się kilka typów azbestu o różnej szkodliwości dla zdrowia [4]. Azbesty wchodzą w skład minerałów dwóch klas: serpentynów i ambifoli [5]. Do pierwszej grupy zalicza się chryzotyl zwany azbestem białym, do drugiej - amozyt (tak zwany azbest brązowy), krokidolit (potocznie zwany niebieskim azbestem), antofilit, tremolit i aktynolit [6-8].

Największe zagrożenie dla zdrowia stanowi azbest niebieski (krokidolit), natomiast w przemyśle najszersze zastosowanie znajduje azbest biały (chryzotyl) - około 90-95\% wszystkich wyrobów azbestowych $[9,10]$, następnie azbest niebieski oraz brązowy (amozyt) [11]. Na rycinie 1 przedstawiono podział odmian azbestu w kontekście ich wykorzystania w przemyśle.

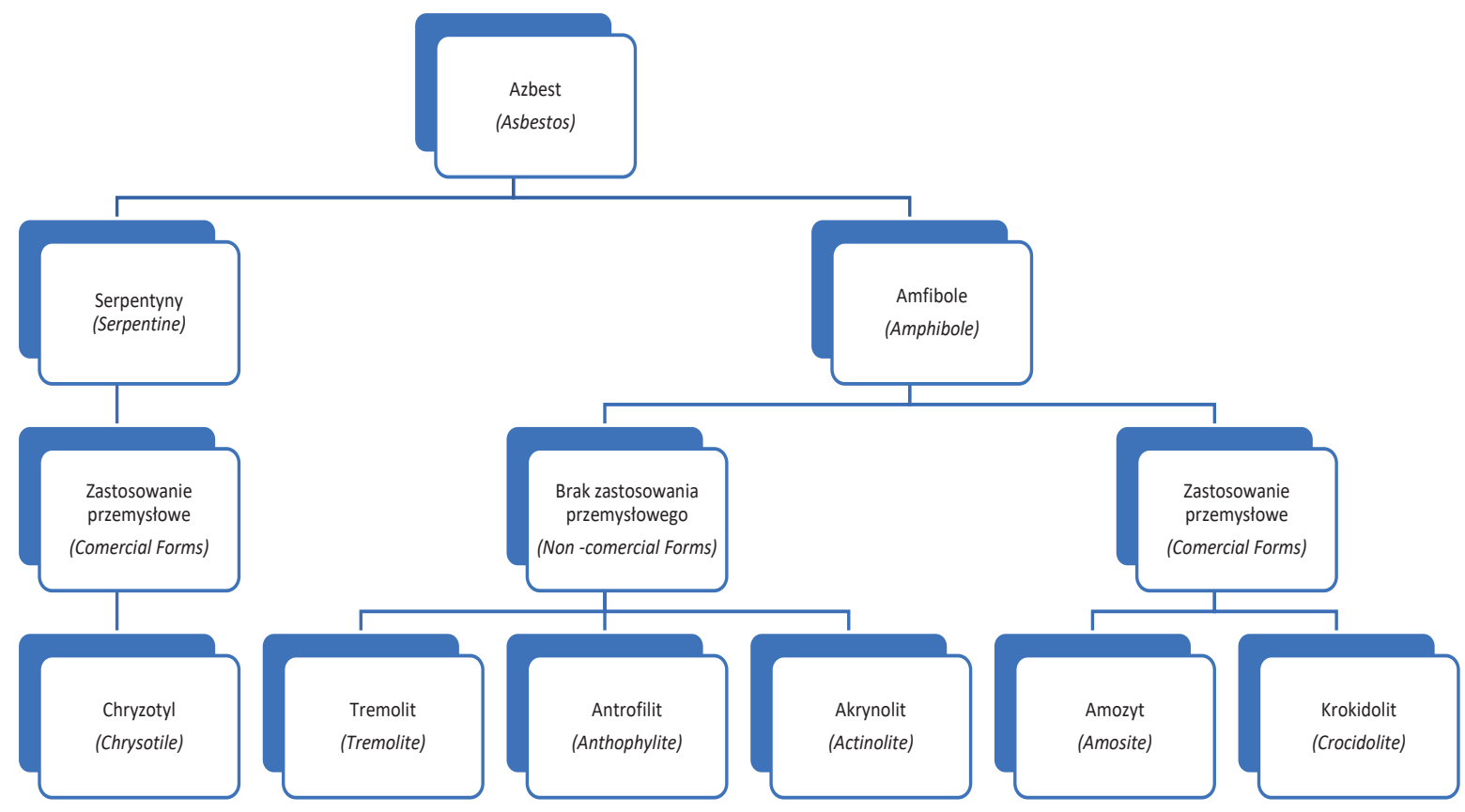

Figure 1. Distribution of varieties of asbestos in the context of their use in industry

Rycina 1. Podział odmian azbestu w kontekście ich wykorzystania w przemyśle

Source / Źródło: T.D. Oury, T.A. Sporn, V.L. Roggli, Erratum to: Pathology of Asbestos-Associated Diseases, Third Edition, w: Pathology of Asbestos-Associated Diseases,: T.D. Oury, T.A. Sporn, V.L. Roggli (red.), Springer Berlin Heidelberg, Berlin, Heidelberg 2016 [12].

The varieties of asbestos differ in terms of their structure and properties. The following table (tab. 1) presents basic information about the respective asbestos varieties.

Asbestos owes its popularity to its unique chemical and physical characteristics [13-15], such as resistance to very high temperatures, chemicals, acids, alkalis and sea water. It is also highly elastic and mechanically durable.

These features caused asbestos to become widely used in the manufacturing of a wide variety of articles, including asbestos-based fabrics, tablecloths, insulation products, tiles, blankets, insulating covers and protective clothing, friction materials and catalysts.

Asbestos was, however, mainly used in the construction industry (fig. 2) [16].
Poszczególne rodzaje azbestu różnią się między sobą budową oraz właściwościami. W poniższej tabeli (tab. 1) przedstawiono zestawienie podstawowych właściwości poszczególnych odmian azbestu.

Azbest popularność zawdzięcza swoim unikalnym właściwościom chemicznym i fizycznym [13-15], takim jak odporność na bardzo wysokie temperatury, działanie chemikaliów, kwasów, zasad oraz wody morskiej. Charakteryzuje się on także dużą sprężystością i wytrzymałością mechaniczną.

Cechy te spowodowały, że znalazł on zastosowanie w produkcji bardzo różnorodnych artykułów, $m$.in. tkanin azbestowych, obrusów, wyrobów izolacyjnych, dachówkek, koców, osłon i kombinezonów izolacyjnych, materiałów ciernych, katalizatorów.

Azbest był wykorzystywany głównie w budownictwie (ryc. 2) [16]. 
Table 1. List of basic information about different asbestos varieties

Tabela 1. Zestawienie podstawowych informacji o różnych odmianach azbestu

\begin{tabular}{|c|c|c|c|c|c|c|}
\hline $\begin{array}{l}\text { Commercial name } \\
\text { Nazwa handlowa }\end{array}$ & $\begin{array}{l}\text { Chrysotile } \\
\text { Chryzotyl }\end{array}$ & $\begin{array}{l}\text { Amosite } \\
\text { Amozyt }\end{array}$ & $\begin{array}{l}\text { Crocidolite } \\
\text { Krokidolit }\end{array}$ & $\begin{array}{l}\text { Tremolite } \\
\text { Tremolit }\end{array}$ & $\begin{array}{l}\text { Actinolite } \\
\text { Aktynolit }\end{array}$ & $\begin{array}{l}\text { Anthophyllite } \\
\text { Antrofilit }\end{array}$ \\
\hline \multirow{2}{*}{$\begin{array}{l}\text { Chemical name } \\
\text { Nazwa chemiczna }\end{array}$} & $\begin{array}{c}\text { Hydrous } \\
\text { magnesium silicate }\end{array}$ & $\begin{array}{l}\text { Iron-magnesium } \\
\text { silicate }\end{array}$ & $\begin{array}{l}\text { Sodium ferric } \\
\text { silicate }\end{array}$ & $\begin{array}{l}\text { Calcium-magnesium } \\
\text { silicate }\end{array}$ & $\begin{array}{l}\text { Calcium silicate } \\
\text { containing } \\
\text { magnesium }\end{array}$ & $\begin{array}{l}\text { Magnesium silicate } \\
\text { containing iron }\end{array}$ \\
\hline & $\begin{array}{c}\text { Uwodniony } \\
\text { krzemian magnezu }\end{array}$ & $\begin{array}{l}\text { Krzemian } \\
\text { żelazowo- } \\
\text { magnezowy }\end{array}$ & $\begin{array}{c}\text { Krzemian } \\
\text { sodowo-żelazowy }\end{array}$ & $\begin{array}{c}\text { Krzemian wapniowo- } \\
\text { magnezowy }\end{array}$ & $\begin{array}{l}\text { Krzemian wapniowy } \\
\text { zawierający magnez }\end{array}$ & $\begin{array}{c}\text { Krzemian } \\
\text { magnezowy } \\
\text { zawierający żelazo }\end{array}$ \\
\hline $\begin{array}{l}\text { Chemical formula } \\
\text { Wzór chemiczny }\end{array}$ & $\begin{array}{c}\mathrm{Mg}_{6} \\
{\left[(\mathrm{OH})_{8} \mathrm{Si}_{4} \mathrm{O}_{10}\right]}\end{array}$ & $\begin{array}{c}(\mathrm{Fe}, \mathrm{Mg})_{7} \\
{\left[(\mathrm{OH}) \mathrm{Si}_{4} \mathrm{O} 11\right]_{2}}\end{array}$ & $\begin{array}{c}\mathrm{Na}_{2} \mathrm{Fe}_{3} \mathrm{Fe}_{2}[(\mathrm{OH}) \\
\left.\mathrm{Si}_{4} \mathrm{O}_{11}\right] 2\end{array}$ & $\mathrm{Ca}_{2} \mathrm{Mg}_{5}\left[(\mathrm{OH}) \mathrm{Si}_{4} \mathrm{O}_{11}\right]_{2}$ & $\begin{array}{c}\mathrm{Ca}_{2}(\mathrm{Mg}) \\
{\left[(\mathrm{OH}) \mathrm{Si}_{4} \mathrm{O}_{11}\right]_{2}}\end{array}$ & $\begin{array}{c}(\mathrm{Mg}, \mathrm{Fe})_{7} \\
{\left[(\mathrm{OH}) \mathrm{Si}_{4} \mathrm{O}_{11}\right]_{2}}\end{array}$ \\
\hline $\begin{array}{l}\text { Density }\left[\mathrm{g} / \mathrm{cm}^{3}\right] \\
\text { Gęstość }\left[\mathrm{g} / \mathrm{cm}^{3}\right]\end{array}$ & $2.2-2.6$ & $2.8-3.6$ & $2.8-3.6$ & $2.9-3.2$ & $3.0-3.2$ & $2.85-3.2$ \\
\hline $\begin{array}{l}\text { Hardness according } \\
\text { to Mohs scale } \\
\text { Twardość w skali } \\
\text { Mosha }\end{array}$ & $5-6$ & $5-6$ & $5-6$ & $5-6$ & $5-6$ & $5-6$ \\
\hline $\begin{array}{l}\text { Decomposition } \\
\text { temperature }\left[{ }^{\circ} \mathrm{C}\right] \\
\text { Temperatura } \\
\text { rozkładu }\left[{ }^{\circ} \mathrm{C}\right]\end{array}$ & $450-700$ & $600-800$ & $400-600$ & $950-1040$ & $620-960$ & $600-850$ \\
\hline $\begin{array}{l}\text { Melting/decomposi- } \\
\text { tion point }\left[{ }^{\circ} \mathrm{C}\right] \\
\text { Temperatura topnienia } \\
\text { rozkładu }\left[{ }^{\circ} \mathrm{C}\right]\end{array}$ & 1500 & 1400 & 1200 & 1315 & 1400 & 1450 \\
\hline $\begin{array}{l}\text { Solubility in acids } \\
\text { Rozpuszczalność } \\
\text { w kwasach }\end{array}$ & 56 & 12 & 3.14 & Brak danych & Brak danych & 2.13 \\
\hline $\begin{array}{l}\text { Solubility in alkalis } \\
\text { Rozpuszczalność } \\
\text { w zasadach }\end{array}$ & 1.03 & 6.82 & 1.2 & Brak danych & Brak danych & 1.77 \\
\hline
\end{tabular}

Source: Own elaboration.

Źródło: Opracowanie własne.

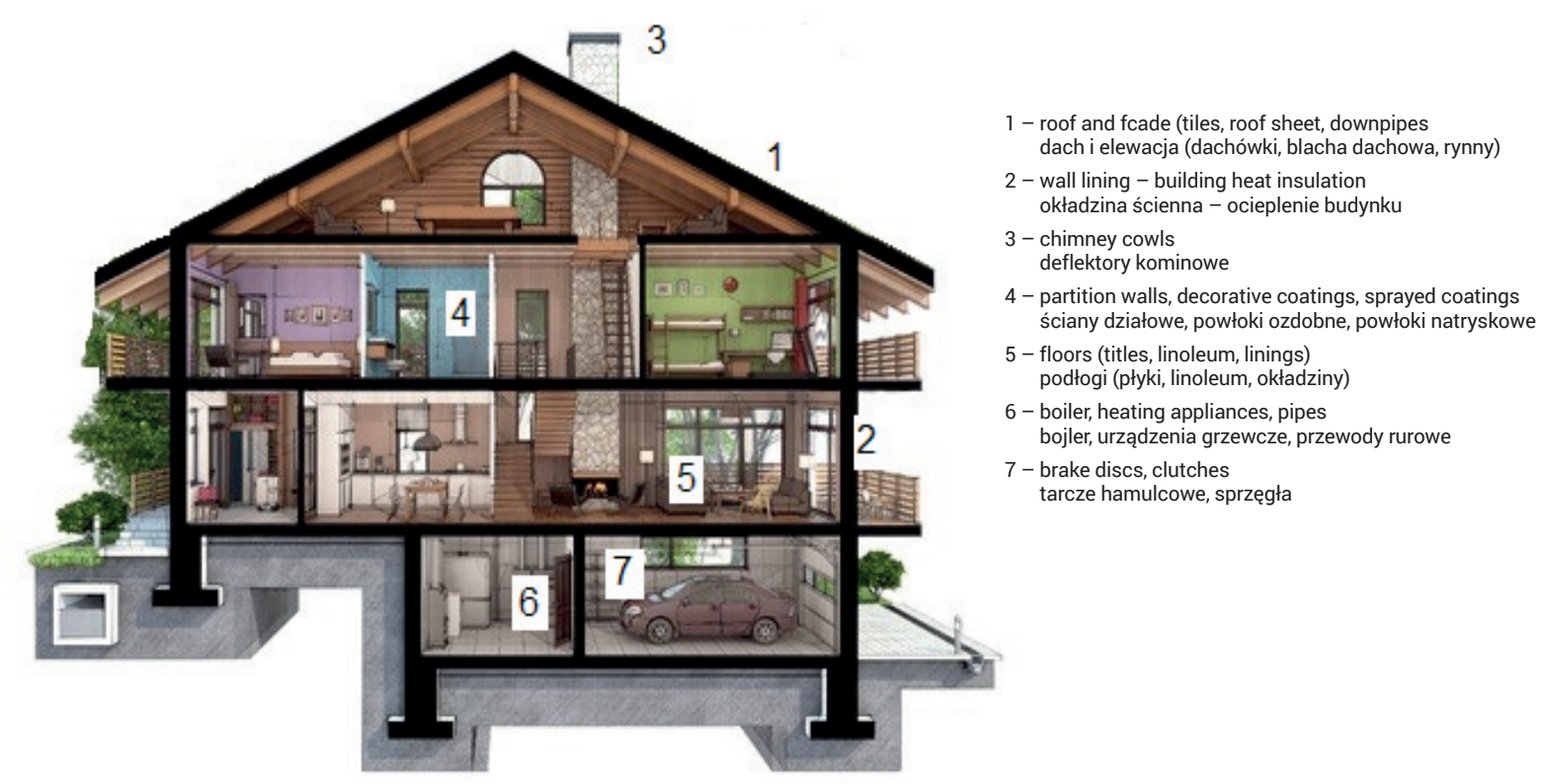

Figure 2. Diagram showing the location of materials that may contain asbestos

Rycina 2. Schemat przedstawiające umiejscowienie materiałów mogących zawierać azbest

Source: Freepik after modifying by the author.

Źródło: Freepik po modyfikacji autora. 
Despite the fact that asbestos products had been widely used between 1950 and 1990, they are now considered problematic, and the widespread use of asbestos is often referred to as one of the greatest technological mistakes made by the mankind [17].

Given its valuable properties, such as softness, flexibility and fire resistance, in the ancient times asbestos had been regarded as silk in the mysterious world of minerals.

Due to its properties, at the time it was referred to as cotton stone or stone flax. The first asbestos-containing products dated as approximately 4500 years old were discovered during excavations in Finland. Similar products were found in Southern Europe, dated as approximately 2500 years old [18]. In those days, asbestos was primarily used to weave tablecloths and tissues.

The wider use of asbestos products is further discussed in chronicles, which mention it being used for manufacturing candle wicks, non-flammable paper and textile products.

The mass extraction and use of asbestos started at the turn of the 20th century, brought about with the industrial revolution [19]. Asbestos began to be used for numerous industrial and commercial applications. Initially, it was used to make gaskets for steam engines $[8,19]$, refractory fabrics for firefighters, and in the construction industry - mainly in the form of asbestos and cement slabs [18].

The largest asbestos deposits are located in Canada and Russia (in the Ural Mountains) [18, 20, 21]. In addition, asbestos was manufactured in numerous countries, including Italy, the United States, South Africa, Zimbabwe, China and Brazil [18]. It is estimated that in the 20th century around 174000000 tonnes of asbestos [18] were manufactured worldwide.

In Poland, asbestos deposits are located mainly in the Lower Silesia region, in Rędziny near Kamienna Góra and in the Sudetes, however, is has never been mined there [22, 23], mainly because it naturally occurs as an impurity in minerals such as melaphyr, gabro, nickel ore and magnesite [23].

Asbestos was widely used in many technologies, e.g. for manufacturing asbestos and cement slabs (in Poland commonly referred to as eternit), textile products (yarns and ropes), friction products (brake discs), waterproofing products (various types of adhesives), floor tiles, filtration materials used in brewing and pharmacy, as well as military gas masks $[18,24]$.

Currently, asbestos is no longer used for manufacturing the products listed above, while still being used in the aerospace industry (for manufacturing rocket engines in the US space shuttle programme) and in the marine industry (in particular in areas exposed to fire requiring increased heat resistance) [24, 25].

After World War II, over two million tonnes of asbestos were imported to Poland. Most of it was used for the production of asbestos and cement slabs [26-28], primarily applied for roofing. The majority of the asbestos and cement slabs were used in the areas currently known as Mazowieckie and Lubelskie Voivodeships, while these components were the least popular in the Opolskie and Lubuskie Voivodeships.

Asbestos and cement slabs were popular mainly due to their competitive prices in comparison to galvanised sheet or roofing tiles.
Mimo szerokiego stosowania wyrobów azbestowych w latach 1950-1990 obecnie produkty zawierające azbest są uważane za problematyczne, a szerokie zastosowanie azbestu niejednokrotnie nazywa się jedną z największych pomyłek technologicznych ludzkości [17].

Azbest charakteryzujący się cennymi cechami - takimi jak miękkość, giętkość, odporność na ogień - w czasach starożytnych postrzegany był jako jedwab tajemniczego świata minerałów.

Początkowo ze względu na właściwości nazywany był kamieniem bawełnianym lub Inem kamiennym. Pierwsze wyroby zawierające azbest pochodzą sprzed ok. 4500 lat i zostały odkryte podczas wykopalisk w Finlandii. W Europie Południowej znaleziono podobne wyroby sprzed ok. 2500 lat [18]. W tamtych czasach azbest wykorzystywano do tkania obrusów i chusteczek.

Szersze zastosowanie wyrobów z azbestem omawiane jest w kronikach, które opisują jego używanie w knotach do świec, niepalnego papieru, a także $w$ wyrobach tekstylnych.

Masowe wydobycie i stosowanie azbestu rozpoczęło się na przełomie XIX i XX wieku wraz z rewolucją przemysłową [19]. Azbest zaczęto stosować w wielu dziedzinach gospodarki i przemysłu. Początkowo używano go do wyrobu uszczelek do silników parowych $[8,19]$, jako ogniotrwałe tkaniny dla strażaków, a także w budownictwie - głównie w formie płyt eternitowych [18].

Największe złoża azbestu zlokalizowane są w Kanadzie i w Rosji (w górach Ural) [18, 20, 21]. Dodatkowo azbest był produkowany we Włoszech, Stanach Zjednoczonych, Republice Południowej Afryki, Zimbabwe, Chinach, Brazylii [18]. Szacuje się, że w XX wieku wyprodukowano na świecie ok. 174000000 ton azbestu [18].

W Polsce azbest występuje w złożach Dolnego Śląska, Rędzinach koło Kamiennej Góry oraz w Sudetach, nigdy jednak nie był tam wydobywany [22, 23] - w głównej mierze z powodu jego występowania w złożach w formie zanieczyszczenia surowców mineralnych takich jak melafir, gabro, rudy niklu czy magnezytu [23].

Azbest stosowano $\mathrm{w}$ wielu technologiach, m.in. do wytwarzania płyt azbestowo-cementowych (czyli tak zwanego eternitu), w produkcji wyrobów włókienniczych (przędze i sznury), wyrobów ciernych (tarcze hamulcowe), wyrobów hydroizolacyjnych (różnego rodzaju lepiki), płytek podłogowych, materiałów filtracyjnych wykorzystywanych w piwowarstwie i farmacji, a także w wojskowych maskach przeciwgazowych $[18,24]$.

Obecnie stosowanie azbestu w produkcji wyżej wymienionych wyrobów zostało zaniechane, natomiast azbest nadal stosuje się w przemyśle kosmicznym (produkcja silników rakietowych w amerykańskim programie wahadłowców kosmicznych) i okrętowym (szczególnie w miejscach narażonych na ogień, wymagających zwiększonej odporności na wysoką temperaturę) [24, 25].

Po Il wojnie światowej do Polski sprowadzono ponad dwa miliony ton azbestu, który w większości został użyty do produkcji płyt azbestowo-cementowych [26-28], wykorzystywanych później głównie na pokrycia dachowe. Najwięcej płyt eternitowych zastosowano na terenach obecnego województwa mazowieckiego i lubelskiego, a najmniej - na terenach województwa opolskiego i lubuskiego.

Popularność stosowania płyt azbestowo-cementowych wynikała głównie z konkurencyjnej - w porównaniu do blachy ocynkowanej czy dachówki - ceny. 


\section{Legal considerations regarding the application of asbestos}

In the mid-1980s, crocidolite asbestos was withdrawn from Poland. Later in 1997 an Act was passed banning the use of products containing asbestos [29]. The Act also specifies the methods and conditions for the safe use and disposal of products containing asbestos.

Such formalised guidelines on the subject were introduced as a method for preventing the growing concerns related to removing asbestos-containing products and the harmful effects of this mineral on human health and body, as confirmed in the 1980s [30].

The Act passed in Poland was also influenced by international efforts for gradually restricting the use of products containing asbestos. The European Economic Community was very active in regulating the manufacturing, use and application of such products, as in 1983 it developed and adopted amendments to Directive 76/769/EEC. These amendments mainly pertained to the regulation of the marketing, use and labelling of products containing asbestos.

1985 saw the introduction of Directive 85/61/EEC, which imposed more severe regulations pertaining to asbestos, as it prohibited these products from being placed on the market or used in toys, sprays, retail powders, tobacco products, catalytic heaters, paints and varnishes [31]. Another document was Commission Directive 91/659/EEC, which adapted to technical progress Annex I to Council Directive 76/769/EEC. The changed legislation placed restrictions on the marketing and use of selected hazardous substances and preparations and placed a ban marketing and use of all types of amphibole asbestos and products containing it [32].

Subsequent EU legislative work resulted in the implementation of Commission Directive 1999/77/EC of 26 July 1999 on the approximation of the laws, regulations and administrative provisions of the Member States relating to restrictions on the marketing and use of certain dangerous substances and preparations (OJ L 207, 6.8.1999) [33]. The amended directive has been in force throughout the European Union's area since 2005.

Regulation 1907/2006 of the European Parliament and of the Council of 18 December 2006 permits introducing and using asbestos shafts for pulling glass in existing installations until they are fully used up or until asbestos-free alternatives are made available [19, 34].

The next document, Council Directive 87/217/EEC, contains provisions on the prevention and reduction of environmental pollution by asbestos. It contains, among others, the basic requirements for taking action to protect the environment from exposure to dust containing asbestos [35]. The European Union has also issued regulations for managing asbestos- containing waste. Therefore, Council Directive 91/689/EEC [36] was developed and implemented, subsequently replaced by Council Directive 94/31/EC [37] and subsequently by Directive 2008/98/EC on waste [38].

On 27 September 2001, the Regulation of the Minister of the Environment on the waste catalogue [39] was introduced in Poland. The regulation categorised asbestos waste into several groups (table 2).

\section{Uwarunkowania prawne dotyczące stosowania azbestu}

W połowie lat osiemdziesiątych XX wieku zaniechano stosowania w Polsce azbestu krokidolitowego. Następnie w 1997 roku uchwalono ustawę o zakazie stosowania wyrobów zawierających azbest [29]. Ustawa ta zawiera informacje o sposobach i warunkach bezpiecznego użytkowania i usuwania wyrobów zawierających azbest.

Przyczyną wprowadzenia wspomnianego dokumentu był rosnący problemem z usuwaniem wyrobów zawierających azbest, a także potwierdzone $w$ latach 80 . ubiegłego stulecia szkodliwe oddziaływanie tego minerału na organizm i zdrowie ludzi [30].

Na powstanie ustawy w Polsce wpływ miały także prace nad wprowadzeniem stopniowych ograniczeń stosowania wyrobów zawierających azbest, prowadzone za granicą. Dużą aktywnością w zakresie uregulowania kwestii związanych z wytwarzaniem, wykorzystaniem i stosowaniem takich wyrobów wykazywała Europejska Wspólnota Gospodarcza, która w 1983 r. wypracowała i uchwaliła zmiany do Dyrektywy 76/769/EWG. Dotyczyły one głównie regulacji wprowadzania do obrotu, stosowania i znakowania wyrobów zawierających azbest.

W 1985 r. wprowadzono Dyrektywę 85/61/EWG, która zaostrzyła przepisy - zgodnie z nią włókna azbestowe nie mogą być wprowadzane do obrotu ani stosowane przy produkcji zabawek, w materiałach i preparatach aerozolowych, produktach detalicznych w proszku, wyrobach tytoniowych, grzejnikach katalitycznych, farbach i lakierach [31]. Kolejnym dokumentem była Dyrektywa Komisji 91/659/EWG, która dostosowała do stanu technicznego załącznik I do Dyrektywy Rady 76/769/EWG. Dostosowanie to tyczyło się ograniczeń wprowadzania do obrotu i stosowania niektórych substancji i preparatów niebezpiecznych - zakaz wprowadzania i stosowania wszystkich rodzajów azbestu amfibolowego oraz jego produktów [32].

Kolejne prace nad prawodawstwem europejskim skutkowały wprowadzeniem Dyrektywy Komisji 1999/77/WE z 26 lipca 1999 r. w sprawie zbliżenia przepisów ustawowych, wykonawczych i administracyjnych państw członkowskich odnoszących się do ograniczeń we wprowadzaniu do obrotu i stosowaniu niektórych substancji i preparatów niebezpiecznych (Dz. U. WEL 207 z 6 sierpnia 1999 r.) [33]. Po zmianach, od 2005 r., dyrektywa ta obowiązuje na terenie całej Unii Europejskiej.

Natomiast w Rozporządzeniu 1907/2006 Parlamentu Europejskiego i Rady z dnia 18 grudnia 2006 r. zapisano, że dopuszcza się wprowadzanie i stosowanie wałów z azbestu, używanych podczas procesu ciągnienia szkła $w$ istniejących instalacjach, do momentu ich zużycia lub do czasu, kiedy dostępne będą bezazbestowe zamienniki [19, 34].

Kolejny dokument - Dyrektywa Rady 87/217/EWG - zawiera przepisy dotyczące ochrony środowiska przed azbestem. Zawarto w niej m.in. podstawowe wymagania dotyczące podjęcia działań mających na celu ochronę środowiska przed ekspozycją na pyły azbestowe [35]. Unia Europejska zadbała również o temat związany z gospodarowaniem odpadami zawierającymi azbest. W związku z tym opracowano i wprowadzono Dyrektywę Rady 91/689/EWG [36], która następnie została zastąpiona Dyrektywą Rady 94/31/WE [37], a następnie Dyrektywą 2008/98/WE w sprawie odpadów [38]. 
Table 2. List of asbestos-containing waste [39]

Tabela 2. Zestawienie odpadów zawierających azbest [39]

\begin{tabular}{|c|c|}
\hline $\begin{array}{l}\text { Group code } \\
\text { Kod grupy }\end{array}$ & $\begin{array}{l}\text { Groups, subgroups and types of waste } \\
\text { Grupy, podgrupy i rodzaje odpadów }\end{array}$ \\
\hline $060701 *$ & Asbestos waste from electrolysis / Odpady azbestowe z elektrolizy \\
\hline $061304^{*}$ & Waste from asbestos processing / Odpady z przetwarzania azbestu \\
\hline 101181 * & Waste containing asbestos / Odpady zawierające azbest \\
\hline $101309 *$ & $\begin{array}{l}\text { Waste containing asbestos from the manufacture of cement and asbestos elements } \\
\text { Odpady zawierające azbest z produkcji elementów cementowo-azbestowych }\end{array}$ \\
\hline $150111 *$ & $\begin{array}{l}\text { Metal packaging containing dangerous porous structural strengthening elements (e.g. asbestos), including empty pressure tanks } \\
\text { Opakowania z metali zawierające niebezpieczne porowate elementy wzmocnienia konstrukcyjnego } \\
\text { (np. azbest), włącznie z pustymi pojemnikami ciśnieniowymi }\end{array}$ \\
\hline $160111^{\star}$ & Brake linings containing asbestos / Okładziny hamulcowe zawierające azbest \\
\hline $160212^{*}$ & Discarded equipment containing free asbestos / Zużyte urządzenia zawierające wolny azbest \\
\hline $170601 *$ & Insulating materials containing asbestos / Materiały izolacyjne zawierające azbest \\
\hline $170605^{\star}$ & Construction materials containing asbestos / Materiały konstrukcyjne zawierające azbest \\
\hline
\end{tabular}

*Hazardous waste

*Odpad niebezpieczny

Countries outside the European Union have developed their own internal regulations for asbestos and products containing asbestos. The level of regulation varies between countries, depending mainly on their development. Developed countries in general have higher level of awareness with regard to the harmful effects of asbestos products, however, the knowledge is not always reflected by legal provisions and consistent actions.

The changes implemented in various countries' legislation in 2000 and 2015 are presented in figure 3. Countries which have not banned asbestos and asbestos materials are highlighted in red, while countries that have significantly restricted or banned asbestos and materials containing asbestos are highlighted in green. White colour designates countries for which no data is available.

Figure 3 shows that the international awareness of the harmfulness of asbestos is increasing. Each year more and more countries are imposing restrictions on the use of the substance.

The use of asbestos and products containing it as a component is banned in 66 countries, mainly highly developed ones $[41,42]$. Despite numerous changes in legislation, countries such as Russia, Brazil, China and Kazakhstan are continuing to manufacture products containing asbestos, while in countries and regions such as India, China, Brazil, Russia and Indonesia products with asbestos still remain widely used $[43,44]$. The continued use of these products is determined by the unique properties of asbestos which are difficult to replace by other materials [30]. In addition, it is often the case that these products are manufactured and used without or with limited protective measures preventing the adverse effects of the mineral.
Dnia 27 września 2001 r. w Polsce wprowadzono Rozporządzenie Ministra Środowiska w sprawie katalogu odpadów [39], gdzie odpady zawierające azbest zostały umieszczone w różnych grupach (tab. 2)

Państwa poza Unią Europejską posiadają swoje wewnętrzne regulacje prawne odnoszące się do azbestu i wyrobów azbestowych. Poziom regulacji prawnych w poszczególnych krajach jest zróżnicowany i w głównej mierze zależy od stopnia ich rozwoju. W państwach wysokorozwiniętych poziom świadomości dotyczący szkodliwości wyrobów jest wyższy, ale nie zawsze idzie w parze z zapisami aktów prawnych i konsekwentnymi działaniami.

Wprowadzanie zmian $\mathrm{w}$ prawodawstwie obowiązującym w latach 2000 i 2015 w poszczególnych krajach świata zobrazowano na rycinie 3 . Kolorem czerwonym zaznaczono państwa, które nie wprowadziły zakazu stosowania azbestu i materiałów azbestowych, a zielonym - kraje, które wprowadziły znaczne ograniczenia lub zakaz stosowania azbestu i materiałów zawierających azbest. Kolor biały oznacza kraje, co do których brak jest danych dotyczących użytkowania azbestu.

Z ryciny 3 wynika, że ogólnoświatowa świadomość szkodliwości azbestu jest coraz wyższa i z roku na rok coraz więcej państw wprowadza obostrzenia w jego stosowaniu.

$\mathrm{Na}$ świecie zabroniono użytkowania azbestu i wyrobów zawierających azbest w 66 krajach - głównie w państwach wysokorozwiniętych [41, 42]. Mimo wielu zmian prawnych w krajach takich jak: Rosja, Brazylia, Chiny i Kazachstan nadal produkowane są wyroby azbestowe, a w krajach i regionach takich jak: Indie, Chiny, Brazylia, Rosja i Indonezja artykuły zawierające azbest nadal są powszechnie używane $[43,44]$. Determinują to unikatowe właściwości azbestu, które są trudne do zastąpienia przez inne materiały [30]. Co gorsza produkcja i stosowanie wyrobów azbestowych odbywa się niejednokrotnie z pominięciem lub tylko z minimalnym wykorzystaniem środków ochrony przed działaniami niepożądanymi tego minerału. 


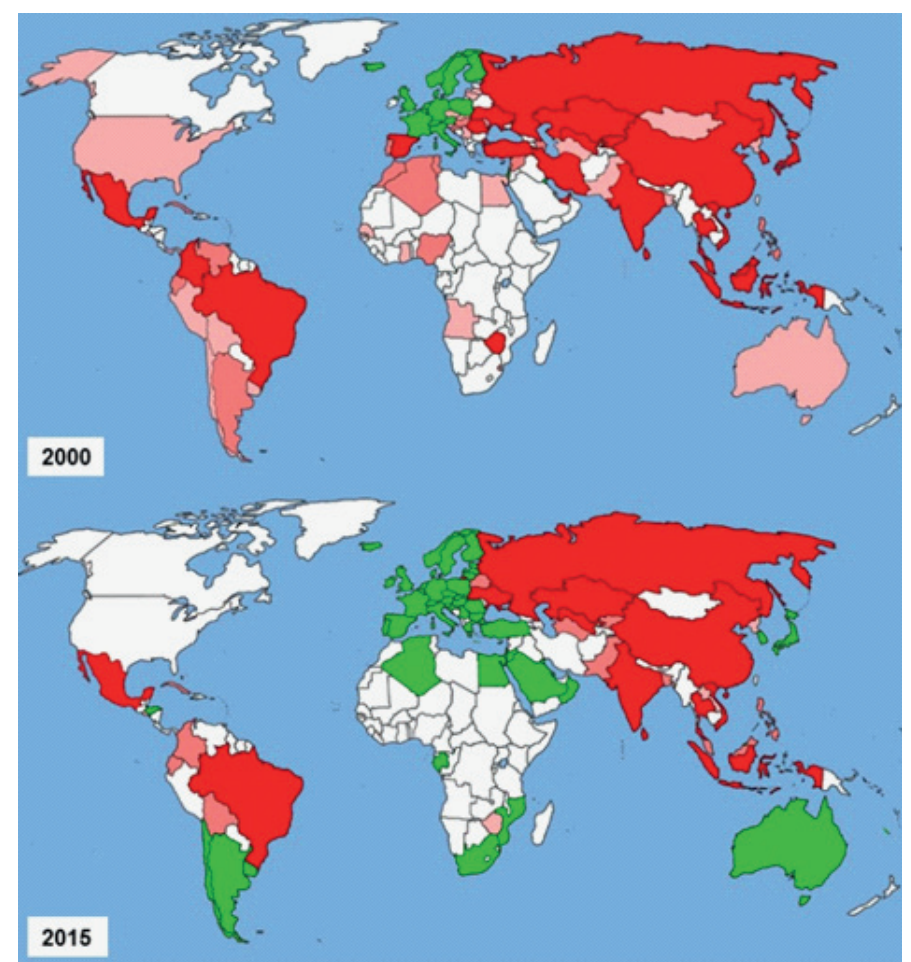

Figure 3. Comparison of the application and introduction of its limitations in 2000 and 2015

Rycina 3. Porównanie stosowania i wprowadzenia jego ograniczeń w latach 2000 i 2015

Source / Źródło: Chronology of Asbestos Bans and Restrictions. http://ibasecretariat.org/chron_ban_list.php [dostęp 22.03.2019].

\section{The impact of asbestos on humans}

Asbestos and its use have a negative impact on both the environment and human life and health [24, 45]. Environmental pollution with asbestos may result from natural processes such as erosion and crumbling of rocks or from the extraction, production, use, disposal or spontaneous destruction of products containing asbestos [46-50].

The harmful effects of asbestos on the human body were already confirmed in the 1970s, and its carcinogenic properties were proven subsequently [51-53].

In terms of human health, the most hazardous component of asbestos are the so-called respirable fibres, which are inhaled into the body along with other contaminants. These fibres are retained in the respiratory tract and contribute to lung diseases [21]. Persons employed for the extraction, processing or disposal of asbestos or asbestos products constitute the main group exposed to the undesirable effects of asbestos fibres. Exposure to asbestos coming from natural sources, the so-called environmental exposure, constitutes a distinct category. However, natural sources have a negligible impact on human morbidity, as they are located in dispersed areas with sparse population [45, 50].

Considering the ban on asbestos products and the necessity to remove asbestos products from the country, a much greater risk is attached to the demolition and disassembly of products containing asbestos [21].

Inhaling asbestos fibres with air [54] or having them enter the digestive tract has negative consequences. Among these adverse

\section{Wpływ azbestu na człowieka}

Azbest negatywnie wpływa na zdrowie i życie ludzi [24, 45]. Stosowanie go jest nieekologiczne. Zanieczyszczenie środowiska azbestem może być efektem procesów naturalnych wietrzenia skał lub też skutkiem wydobycia, produkcji, użytkowania, usuwania lub samoistnego niszczenia wyrobów azbestowych [46-50].

Szkodliwe oddziaływanie azbestu na organizm ludzki potwierdzono już w latach 70 . ubiegłego wieku, a następnie udowodniono jego kancerogenność [51-53].

Dla człowieka najgroźniejsze są tak zwane włókna respirabilne, które dostają się do organizmu poprzez wdychanie powietrza wraz z zanieczyszczeniami. Włókna te zatrzymują się w układzie oddechowym i są przyczynkiem do chorób płuc [21]. Narażone na niepożądane działanie włókien azbestu są głównie osoby pracujące przy wydobyciu, przetwarzaniu lub usuwaniu azbestu bądź też wyrobów azbestowych. Wyróżnia się również narażenie na azbest pochodzący ze źródeł naturalnych - tak zwaną ekspozycję środowiskową. Jednakże źródła naturalne mają znikomy wpływ na zachorowalność ludzi, gdyż znajdują się one na terenach mało zaludnionych i są rozproszone $[45,50]$.

Natomiast ze względu na zakaz produkcji wyrobów azbestowych i konieczność usuwania z terenów kraju wyrobów azbestowych największe zagrożenie powodują prace rozbiórkowe i demontażowe wyrobów zawierających azbest [21].

Dostawanie się włókien azbestowych do organizmu człowieka z wdychanym powietrzem [54] czy drogą pokarmową niesie 
effects are lung diseases (including lung cancer), asbestosis, pleural lesions and pleural mesothelioma [28, 55]. Figure 4 demonstrates the severity of the problem, as it presents the number of cases of asbestosis in Poland between 1970 and 2016. The risk of developing cancer of the larynx, throat, stomach, ovaries and other tissues is also increased $[23,27,50,56,57]$. ze sobą negatywne skutki. Wśród takich niepożądanych skutków należy wymienić choroby płuc (w tym choroby nowotworowe płuc), pylicę azbestową, zmiany opłucnej czy też międzybłoniak opłucnej $[28,55]$. Dla zobrazowania stopnia problemu na rycinie 4 przedstawiono liczbę zachorowań na pylicę azbestową w Polsce w latach 1970-2016. Zwiększone jest również ryzyko zachorowań na nowotwory krtani, gardła, żołądka, jajników oraz innych tkanek $[23,27,50,56,57]$.

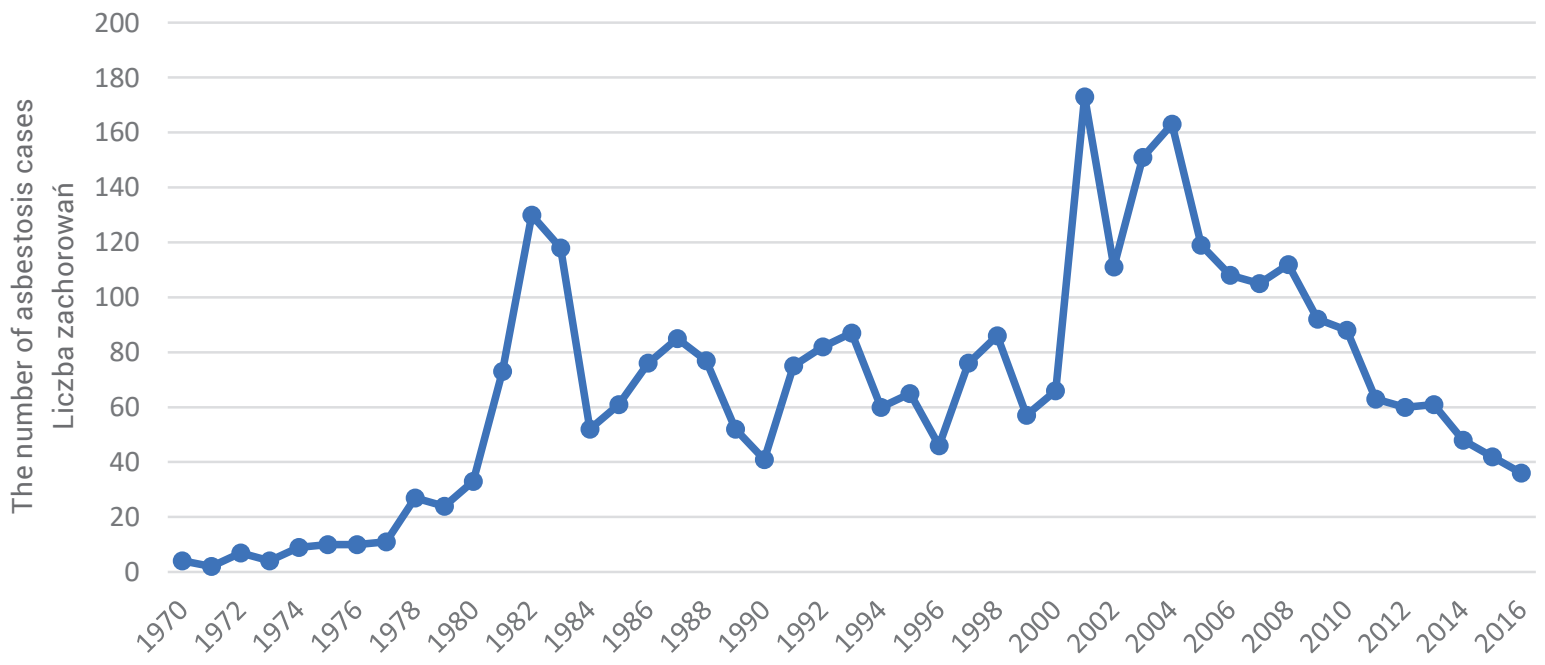

Figure 4. The number of asbestosis cases in Poland in 1970-2016

Rycina 4. Liczba zachorowań na pylicę azbestową w Polsce w latach 1970-2016

\section{Disposal of asbestos and products containing asbestos}

Changes in national legislation force the gradual removal of products containing asbestos. This study is carried out on the basis of the programme "Elimination of asbestos and asbestoscontaining products used in Poland", which is based on the resolution adopted by the Sejm of the Republic of Poland of 19 June 1997 on the programme for removing asbestos and products containing asbestos used in Poland [73] and the Act of 19 June 1997 [29] on the prohibition of the use of products containing asbestos and secondary legislation.

The planned completion date for removing all asbestos products is 2032 [74]. This obligation was imposed by the legal provisions; however, the Act does not assign that task to any official body, but rather spreads it out over multiple authorities.

The disposal of asbestos and products containing asbestos is a complicated issue. Currently, asbestos utilisation is carried out in five ways:

- chemical degradation of asbestos - conversion of asbestos into non-fibrous forms or components of harmless products;

- physical degradation of asbestos;

- biological degradation of asbestos (natural degradation);

\section{Unieszkodliwianie azbestu i wyrobów azbestowych}

Zmiany w prawodawstwie krajowym zobowiązują do stopniowego usuwania wyrobów azbestowych. Prace te prowadzone są na podstawie „Programu usuwania azbestu i wyrobów zawierających azbest stosowanych na terytorium Polski", który opiera się na rezolucji Sejmu Rzeczypospolitej Polskiej z 19 czerwca 1997 roku w sprawie programu wycofywania azbestu i wyrobów zawierających azbest, stosowanych na terytorium Polski [73] oraz ustawy z dnia 19 czerwca 1997 roku [29] o zakazie stosowania wyrobów zawierających azbest oraz odpowiednich aktów wykonawczych do niej.

W Polsce prace nad całkowitym usuwaniem wyrobów azbestowych mają zostać zakończone w 2032 roku [74]. Obowiązek ten został narzucony odgórnie, ale prawodawstwo nie przypisało tego zadania jednemu resortowi, a zobowiązało do tego wiele organów.

Unieszkodliwianie azbestu i wyrobów zawierających azbest jest trudnym zagadnieniem. Obecnie utylizację głównie prowadzi się pięcioma sposobami:

- chemiczna degradacja azbestu - przekształcenie azbestu w formy niewłókniste lub składniki niegroźnych wyrobów;

- fizyczna degradacja azbestu;

- biologiczna degradacja azbestu (naturalna degradacja);

- składowanie azbestu na składowiskach powierzchniowych; 
- storage of asbestos in surface disposal sites;

- storage of asbestos in underground storage sites (e.g. in mining excavation sites).

The chemical degradation of asbestos products is not a simple task, mainly because of its relatively high chemical resistance. Substances such as hydrofluoric acid and fluorosulphonic acid completely dissolve asbestos [75-77], but introducing fluoride into the environment is as controversial as the use of asbestos. Research shows that heating asbestos with borax and a mixture of orthophosphoric acid with ammonium fluoride at a temperature of approximately $500^{\circ} \mathrm{C}$ can potentially neutralise asbestos fibres, causing the total degradation of asbestos structure and turning it into an amorphous structure [78]. Another way to neutralise asbestos is to rinse out magnesium and iron ions with polycarboxylic acids [79] in conjunction with ultrasound and high temperature. Another method used to neutralise asbestos involves a combination of chemical degradation and mechanical operations, such as grinding, which facilitates the chemical degradation of asbestos $[80,81]$.

The physical degradation of asbestos is carried out mainly through the application of high temperatures of $500^{\circ} \mathrm{C}, 700^{\circ} \mathrm{C}$, $950^{\circ} \mathrm{C}$ and $1050^{\circ} \mathrm{C}[53,82-84,84]$. The most commonly used thermal process involves burning asbestos slabs at $1200^{\circ} \mathrm{C}$, which leads to a product resembling clinker [52, 82, 85]. It is also possible to neutralise asbestos through microwave treatment $[86,87]$.

Biological degradation of asbestos products involves the use of natural mosses, lichens or algae in the aquatic environment, which degrade those products by releasing organic acids $[88,89]$. However, these processes occur at normal temperatures, and thus take a long time. Therefore, spontaneous natural degradation is not viable as a natural method for solving the issues related to asbestos products. Nature should be observed and used as a source of knowledge, aiming at combining natural processes with mechanical or thermal processing [13].

The large-scale method used currently involves storing asbestos on surface disposal sites $[90,91]$. The disposal of asbestos in this case consists in storing asbestos products in adequately prepared locations in municipal landfills. The procedure is cheap, however, it requires constant monitoring of such landfills and has a negative impact on the aesthetics of the landscape and on the environment.

Another method for neutralising asbestos and asbestos products includes underground storage, most often in mining excavation sites. This method involves storing asbestos products in unused mines and then backfilling them in order to rehabilitate the area [49]. This operation, however, requires ongoing hydrological monitoring [92].

In addition to the aforementioned methods of eliminating asbestos-containing waste and products, many other methods are at the stage of experimental research and laboratory testing. These include, for example vitrification, which consists in "neutralising" the undesirable properties of asbestos in temperatures of $1,500^{\circ} \mathrm{C}$ [93]. The final product of that is an amorphous substance with high hardness which can be used for construction. The disadvantage of that process is that it requires large amounts of electricity [24].
- składowanie azbestu na składowiskach podziemnych (np. w wyrobiskach kopalnianych).

Chemiczna degradacja wyrobów azbestowych nie jest prosta, ponieważ są to substancje o stosunkowo dużej odporności chemicznej. Istnieją substancje - takie jak kwas fluorowodorowy i kwas fluorosulfonowy - całkowicie trawiące azbest [75-77], jednakże wprowadzanie do środowiska fluoru jest nie mniej kontrowersyjne od wprowadzenia azbestu. Badania wygrzewania azbestu z boraksem i mieszaniną kwasu ortofosforowego z fluorkiem amonu przeprowadzone $w$ temperaturze ok. $500^{\circ} \mathrm{C}$ wykazały możliwość neutralizacji włókien azbestu - całkowitej degradacji struktury azbestu i powstania struktury amorficznej [78]. Innym sposobem neutralizacji azbestu jest wypłukanie $z$ jego struktur jonów magnezu i żelaza kwasami wielokarboksylowymi [79], przy wspomaganiu ich działania ultradźwiękami i podwyższoną temperaturą. Wykorzystuje się również połączenie degradacji chemicznej z operacjami mechanicznymi, takimi jak np. mielenie, które ułatwia chemiczną degradację azbestu [80, 81].

Fizyczna degradacja azbestu jest prowadzona głównie poprzez oddziaływanie termiczne wysokich temperatur $500^{\circ} \mathrm{C}$, $700^{\circ} \mathrm{C}, 950^{\circ} \mathrm{C}$ i $1050^{\circ} \mathrm{C}[53,82-84,84]$. Najczęściej stosowany proces termiczny to wypalanie eternitu w temperaturze $1200^{\circ} \mathrm{C}$, dzięki czemu otrzymuje się produkt przypominający klinkier [52, 82, 85]. Możliwe jest również unieszkodliwianie azbestów spoprzez działanie mikrofal [86, 87].

Biologiczna degradacja wyrobów azbestowych jest metodą naturalnego oddziaływania mchów, porostów lub glonów w środowisku wodnym, które wydzielając kwasy organiczne, prowadzą do degradacji takich wyrobów [88, 89]. Ponieważ jednak procesy te zachodzą $w$ temperaturach normalnych, wymagają długiego czasu. W związku z tym nie należy liczyć na samoistną naturalną degradację i samoistne rozwiązanie problemu wyrobów azbestowych. Naturę należy obserwować i próbować z niej czerpać wiedzę, łącząc działanie natury z obróbkami mechanicznymi lub termicznymi [13].

Składowanie azbestu na składowiskach powierzchniowych jest obecnie metodą stosowaną na szeroką skalę [90, 91]. Unieszkodliwianie azbestu w taki sposób polega na składowaniu wyrobów azbestów w odpowiednio przygotowanych miejscach znajdujących się na składowiskach komunalnych. Opisany sposób postępowania - choć stosunkowo tani - wymaga ciągłego monitorowania takich składowisk oraz wpływa negatywnie na estetykę krajobrazu i środowisko.

Inną metodą unieszkodliwiania azbestu i wyrobów azbestowych jest składowanie podziemne, które najczęściej odbywa się w wyrobiskach górniczych. Metoda ta polega na składowaniu wyrobów w nieczynnych kopalniach, a następnie zasypywaniu ich w celu rekultywacji terenu [49]. Podczas wykonywania tego typu operacji konieczny jest stały monitoring hydrologiczny [92].

Poza wyżej przedstawionymi metodami eliminacji odpadów i wyrobów zawierających azbest wiele innych znajduje się na etapie badań eksperymentalnych i testowanych w skali laboratoryjnej. Wśród nich można wymienić między innymi metodę witryfikacji, która polega na „unieszkodliwianiu” niepożądanych właściwości azbestu poprzez działanie temperatur $1500^{\circ} \mathrm{C}$ [93]. Produktem końcowym tak przeprowadzonego procesu jest 
Disposal can also be carried out using a method referred to as MTT (Microwave Thermal Treatment). That method is based on the simultaneous use of mechanical and thermal processing in a high-energy reactor (temperatures of approximately $900-1100^{\circ} \mathrm{C}$ ) using microwave energy. During the process, crystalline asbestos fibres are torn and transformed into an amorphous form. The final product of that process is neutral to the environment, as well as to humans and animals. It can be used for industrial purposes, e.g. as a filler for concrete mixes [93, 94].

Another noteworthy method for neutralising asbestos involves microwave thermal inertisation. That process alters asbestos fibres and transforms it into an inert magnesium oxide $[85,95]$.

Another disposal method involves plasma destruction technology. Plasma makes it possible to obtain temperatures in the range between $5000-20000^{\circ} \mathrm{C}$ in an anaerobic atmosphere, which enables the decomposition of inorganic compounds. The main products of that process include $\mathrm{CO}, \mathrm{H}_{2}, \mathrm{CO}_{2}, \mathrm{HCl}$ and inorganic waste, vitrite. The gases produced during the process can be converted into a gas fuel. The final product, on the other hand, is amorphous and can be used for manufacturing construction elements or in road construction [92].

Currently, the most frequently used method of asbestos disposal in Poland involves its storage in designated areas. Since 2010 (i.e. since the introduction of the resolution [73]), only part of asbestos waste has been disposed of; the relevant data is presented in figure 5 . amorficzna substancja charakteryzująca się wysoką twardością, która może być stosowana w budownictwie. Wadę stanowi tu konieczność dostarczenia do realizacji procesu dużych ilości energii elektrycznej [24].

Utylizację można również prowadzić przy wykorzystaniu MTT (Microwave Thermal Treatment). Metoda ta polega na jednoczesnym użyciu obróbki mechanicznej oraz obróbki termicznej w wysokoenergetycznym reaktorze (temp. ok. 900-1100 wykorzystującym energię mikrofalową. W trakcie procesu krystaliczne włókna azbestu poprzez rozrywanie zamieniane są na formę bezpostaciową. Produkt końcowy takiego procesu jest obojętny dla środowiska, a także dla ludzi i zwierząt. Z powodzeniem może być wykorzystywany w przemyśle np. jako wypełniacz do mas betonowych [93, 94].

Wartą uwagi metodą unieszkodliwiania azbestu jest również inertyzacja z grzaniem mikrofalowym. Tak przeprowadzony proces powoduje modyfikację struktur włóknistych azbestu z jednoczesnym przekształceniem go w obojętny tlenek magnezu $[85,95]$.

Kolejny sposób utylizacji to zastosowanie technologii plazmowej destrukcji. Plazma pozwala uzyskać temperatury rzędu $5000-20000^{\circ} \mathrm{C} w$ atmosferze beztlenowej, co umożliwia rozkład związków nieorganicznych. W procesie tym głównymi produktami są $\mathrm{CO}, \mathrm{H}_{2}, \mathrm{CO}_{2}, \mathrm{HCl}$ oraz odpady nieorganiczne - witryt. Powstające $w$ trakcie procesu gazy mogą zostać przetworzone na paliwo gazowe. Natomiast produkt końcowy jest amorficzny i może być wykorzystywany do wytwarzania elementów budowlanych lub w budownictwie drogowym [92].

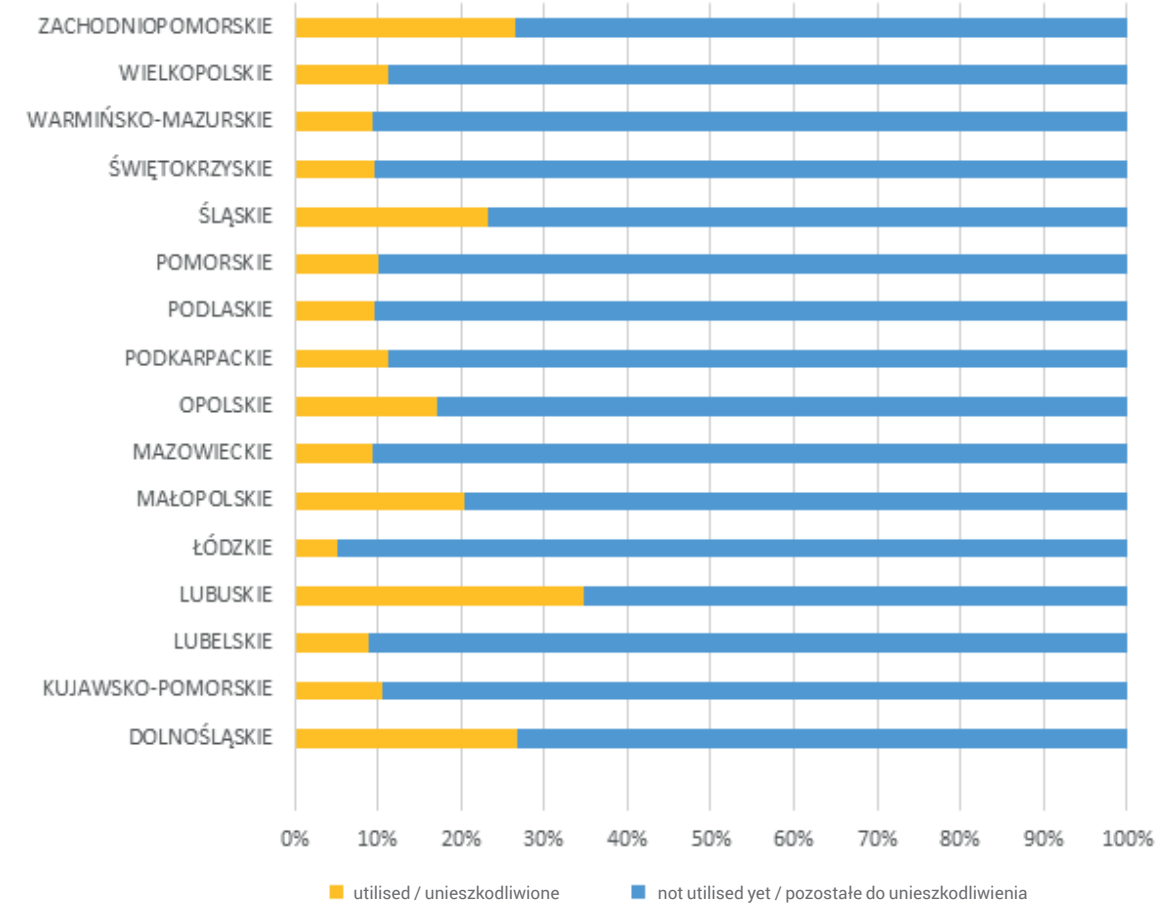

Figure 5. Statistical summary of the utilisation of asbestos and asbestos products in Poland [44, 96]

Rycina 5. Zestawienie statystyczne utylizacji azbestu i wyrobów azbestowych w Polsce [44, 96] 
Considering the fact that half of the time limit envisaged by the legislator for the complete elimination of asbestos from Poland has already passed, the results achieved in individual voivodeships are not optimistic.

\section{Hazards related to rescue and firefighting operations}

Construction materials containing asbestos are still found in many residential and commercial buildings. Asbestos occurs most commonly in asbestos and cement slabs, which have been used as roofing or insulation for buildings.

During a fire, building materials containing asbestos usually crack or crumble. In the event of a fire in a building with components containing asbestos, flakes of asbestos may be released as a result of a pressure build-up inside the component. Such fires may create asbestos debris, including unburned and partially burned asbestos. Some materials containing asbestos are prone to severe damage by fire. Air monitoring during and after fires indicates that asbestos fibre concentrations are usually very low. The probable cause may be the low number of fibres getting released into the air and the large volumes of air circulating as a result of fire. Asbestos fibres are also prone to degradation when exposed to high temperatures for a sufficiently long time.

Asbestos fibres pose a health hazard only if they are respirable. Construction materials containing asbestos may release small fibre particles into the air. However, air monitoring of fires in progress and after their extinguishing shows that very low amounts of asbestos fibres are generated. After each fire, asbestos levels in the air return to the normal levels observed prior to the fire [97].

Moving around an area with building materials containing asbestos or where the wind blows over such materials is unlikely to cause an increase of asbestos amounts in the air. Significant exposure to asbestos fibres occurs when asbestos products are dismantled or during the demolition of buildings damaged by fire. Demolitions must be carried out safely and carefully in order to ensure the lowest possible levels of asbestos fibres in the air.

In general, asbestos in buildings damaged by fires does not pose a high risk to public health. However, there are cases when firefighters and other services are exposed to the negative impact of asbestos [98]. This was the case, among others, during the works carried out on "Ground Zero" after the terrorist attack on the World Trade Center in 2001 [99]. It is estimated that approximately 5000 tonnes of asbestos were used for the construction of the WTC [100]. The component was used, among others, in the northern tower in insulating elements, drywalls, fireproof materials and lift shafts up to the 40th floor [101]. When the WTC buildings collapsed due to the attack,
Aktualnie najczęściej stosowaną metodą unieszkodliwiania azbestu w Polsce jest jego składowanie we wskazanych specjalnie przeznaczonych do tego celu miejscach. Od roku 2010 (czyli od wprowadzenia rezolucji [73]) do dnia dzisiejszego unieszkodliwiono tylko część odpadów azbestowych, co zostało zobrazowane na rycinie 5 .

Biorąc pod uwagę, że minęła połowa czasu narzuconego przez prawodawcę do całkowitego unieszkodliwienia azbestu z terenu Polski, to efekty działań poszczególnych województw nie napawają optymizmem.

\section{Zagrożenia podczas działań ratowniczo- -gaśniczych}

Materiały budowlane zawierające azbest wciąż znajdują się $\mathrm{w}$ wielu budynkach mieszkalnych oraz budynkach gospodarczych. Najczęściej azbest występuje w płytach eternitowych, które były używane jako pokrycia dachowe lub jako docieplenia budynków.

Podczas pożaru materiały budowlane zawierające azbest zazwyczaj pękają lub kruszą się. W trakcie pożarów budynków, w których zastosowano materiały azbestowe, może dochodzić do uwalniania płatków materiału azbestowego (np. z eternitu) wskutek nagromadzenia ciśnienia wewnątrz materiału. Takie pożary mogą powodować powstawanie szczątków azbestu, Monitorowanie powietrza podczas pożarów i po ich ugaszeniu wskazuje, że stężenia włókien azbestu są zazwyczaj bardzo niskie. Prawdopodobnie wynika to z niskiej liczby włókien faktycznie uwolnionych do powietrza i dużych objętości powietrza krążących wskutek pożaru. Włókna azbestowe mogą również ulec destrukcji po wystawieniu ich na działanie wysokich temperatur przez wystarczająco długi czas.

Włókna azbestowe stanowią zagrożenie dla zdrowia tylko wtedy, gdy są tzw. respirabilne. W przypadku materiałów budowlanych zawierających azbest możliwe jest uwalnianie drobnych włókien do powietrza. Jednak monitorowanie stanu powietrza podczas pożarów oraz po ich ugaszeniu wykazało, że włókien tych jest niewiele. Po pożarze zawartość azbestu w powietrzu wraca do typowych poziomów (sprzed pożaru) [97].

Poruszanie się po obszarze, w którym znajdują się materiały budowlane zawierające azbest lub wiatr wiejący nad takim obszarem, prawdopodobnie nie spowodują wytworzenia znacznych ilości azbestu w powietrzu. Znaczne narażenie na wdychanie włókien azbestowych występuje podczas demontażu wyrobów azbestowych lub wyburzania budynku zniszczonego przez pożar. Prace rozbiórkowe i wyburzeniowe muszą być wykonywane z zachowaniem bezpieczeństwa i wszelkiej ostrożności, tak aby zapewnić utrzymanie bardzo niskiego poziomu włókien azbestu w powietrzu.

Ogólnie rzecz biorąc, azbest w budynkach zniszczonych przez pożary zazwyczaj stanowi nikłe zagrożenie dla zdrowia publicznego. Istnieją jednak sytuacje, gdy strażacy i pracownicy innych służb są narażeni na negatywne działanie azbestu [98]. Działo się tak m.in. podczas prac prowadzonych na gruzowisku powstałym po zamachu terrorystycznym na World Trade Center w 2011 r. [99]. Szacuje się, że do budowy WTC użyto ok. 5000 ton 
a considerable volume of dust was elevated into the air, possibly containing asbestos.

It is estimated that approximately 400000 people were exposed to the possibility of inhaling the dust generated during that disastrous event. They included mainly the participants of rescue operations carried out in the area as well as the cleaning personnel hired after the rescue operations had been completed. However, air analysis showed that ambient exposure to asbestos has only slightly increased the risk of cancer among Lower Manhattan residents $[102,103]$.

The literature shows little evidence of the danger posed by asbestos in a burning building. However, following the attack on WTC, studies have shown [104] that blood and urine analyses of 370 firefighters participating in the works carried out at the WTC site were mainly exposed to PAHs, which are known combustion products. In addition, antimony, lead and dioxins and furans were detected in the samples taken, but the quantity of these substances was within the norm. The author of the research indicates that the detection of other substances (including, among others, asbestos and glass fibres) was not possible [104].

The study titled The public health significance of asbestos exposures from large scale fires [102] stressed that the majority of asbestos released in the event of a fire is in the form of clustered non-respiratory fibres. Also, some fibres are subject to "denaturation" as a result of a fire. This means that the amount of respirable fibres is fairly small. In addition, these fibres are dispersed with large air masses moving around with fires and their amount in any given area depends mainly on the temperature of the fire and the amount of emitted heat, the distance from the fire (the further away the smaller the concentration of fibres) and meteorological conditions [102].

Similar conclusions were drawn in the study carried out by N.J. Lewis and M.F. Curtis [105], focusing on the results of air tests after the Birmingham warehouse fire. The authors of the study tested the air samples taken between 1-18 days after the fire by means of phase contrast microscopy (PCM). It determined that the amount of fibres detected in the samples was within the accepted standards [105].

Similar tests were also carried out after the Tranmere factory fire, which took place in England on 22 September 1994, except that in this case no samples were taken immediately after the fire, and the tests involved precipitation samples. These samples also contained asbestos fibres in the amounts not exceeding the standards $[102,106]$.Despite the results of the study $[102,104,105]$, the authors stated that diseases caused by the inhalation of asbestos most often begin to develop after around 20-30 years of exposure, therefore it is predicted that an increase in the number of asbestos-related diseases will begin to rise between 2030 and 2040 [107]. It is therefore extremely important to perform the ongoing monitoring of the health of persons with the highest exposure during rescue and firefighting operations, i.e. firefighters-rescuers.

In the event of fire involving the combustion of asbestos components, it is recommended for the service personnel within 300 metres around the fire to use personal protective equipment. Firefighters, as the persons closest to the danger azbestu [100]. Wykorzystywano go między innymi w wieży północnej w elementach izolacyjnych, płytach gipsowo-kartonowych, materiałach ognioodpornych i w szybach windowych do 40 piętra [101]. Po zawaleniu się wskutek ataku budynków WTC w powietrze uniesione zostały pyły zawierające prawdopodobnie również azbest.

Z danych szacunkowych wynika, że ok. 400000 ludzi było narażonych na wdychanie pyłów z tej katastrofy. Byli to głównie uczestnicy akcji ratowniczych z gruzowiska oraz osoby porządkujące teren WTC po zakończeniu działań ratowniczych. Po wykonanych analizach powietrza stwierdzono jednak, że narażenie na działanie azbestu w otaczającym powietrzu spowodowało jedynie nieznaczny wzrost ryzyka wystąpienia raka u mieszkańców Dolnego Manhattanu [102, 103].

W literaturze tematu istnieje niewiele materiałów mówiących o zagrożeniu, jakie może powodować azbest będący np. w palącym się budynku. Jednakże po ataku na WTC pojawiły się opracowania [104] podające, że z analiz krwi i moczu pobranych od 370 strażaków biorących udział w akcji na gruzowiskach WTC wynika, że strażacy byli w głównej mierze narażeni na WWA, które są znanymi produktami spalania. Ponadto w pobranych próbkach wykryto obecność antymonu, ołowiu, oraz związków z grupy dioksyn i furanów, jednakże ilość tych substancji zawierała się w ustalonych normach. Autor badań wskazuje, że ustalenie obecności innych substancji ( $w$ tym m.in. azbestu i włókien szklanych) było niemożliwe [104].

W pracy pt. The public health significance of asbestos exposures from large scale fires [102] podkreślono, że podczas pożaru większość azbestu zostanie uwolniona w postaci skupisk włókien, które nie będą respirabilne. Również część włókien w trakcie pożaru ulegnie „denaturacji”. Oznacza to, że ilość włókien respirabilnych będzie mała. Dodatkowo włókna te ulegną rozproszeniu poprzez ruch dużych mas powietrza towarzyszących pożarom i ich ilość w danym miejscu będzie zależna w głównej mierze od temperatury pożaru i ilości ciepła przez niego wydzielanego, odległości od pożaru (im dalej tym mniejsze stężenie włókien) oraz warunków metrologicznych [102].

Podobne wnioski zostały zawarte w pracy N.J. Lewis i M.F. Curtis [105] opisującej wyniki badań powietrza po pożarze magazynu w Birmingham. Autorzy badania przeprowadzili na próbkach powietrza pobranych $w$ okresie 1-18 dni po pożarze i poprzez zastosowanie analizy z użyciem mikroskopii z kontrastem fazowym (PCM) określili, że ilość włókien wykrytych w próbkach mieści się w przyjętych normach [105].

Analogiczne badania wykonano również po pożarze fabryki w Tranmere w Anglii 22 września 1994 roku. W tym przypadku pobrane i zbadane próbki pochodziły z opadów atmosferycznych. Wyniki wykazały obecność włókien azbestowych w ilościach nieprzekraczających norm [102, 106].

Mimo otrzymanych wyników badań [102, 104, 105] autorzy stwierdzili, że ze względu na to, że choroby wywołane wdychaniem azbestu najczęściej zaczynają rozwijać się po ok. 20-30 latach od ekspozycji, przewiduje się, że wzrost zachorowań na choroby azbestowe będzie notowany w latach 2030-2040 r. [107]. Dlatego też niezmiernie ważne jest monitorowanie stanu zdrowia osób, które były najbardziej narażone podczas prowadzenia działań ratowniczo-gaśniczych, czyli strażaków ratowników. 
[102, 108], should absolutely use breathing apparatus to avoid breathing in asbestos-containing dust. Most of the protective equipment used by firefighters eliminates exposure to fibres, but in the secondary stages of rescue and firefighting operations, firefighters happen to remove protective equipment for greater comfort of work, being unaware of the presence of high levels of asbestos fibres in the air.

The application of numerical modelling in the monitoring the release of asbestos dust or thermal decomposition products through the dispersion of such pollutants in the atmosphere may be helpful in such cases. However, the background levels $[102,109,110]$ must also be taken into account. Taking advantage of the possibilities offered by numerical modelling may also prove useful for the persons responsible for managing rescue operations [111].

In addition, good working practice shows that spraying water on debris during demolition or after collapse is advisable to ensure that the dust, including the asbestos- containing dust, remains at a relatively low level. However, in a massive event such as the collapse of the WTC towers, that solution was impossible [112].

\section{Summary and conclusions}

Asbestos and asbestos-containing products have gone through a difficult path, ranging from the initial interest and widespread use to severe manufacturing and use restrictions. Asbestos products have unique properties, but their disposal is particularly difficult. The disposal and processing of asbestos is a difficult process. When eliminating asbestos products, care must be taken to ensure that the process does not cause even greater issues for people and the environment than the use of asbestos itself.

Continuous efforts should be made to optimise and accelerate the degradation and disposal of asbestos products, as well as to ensure that Poland obtains and reserves sufficient funds to remove the harmful materials from households and heating systems (i.e. from everyday use) within the deadlines set out in the "Asbestos Removal Programme".

Although numerous asbestos disposal technologies have been developed, they are often small-scale technologies that are either unsuitable for industrial applications or not economically viable. Another disadvantage of the developed technologies is that the materials used for processing and neutralising asbestos (e.g. fluorine and its compounds) are more harmful to the environment than the neutralised mineral itself. On the other hand, however, technologies exist which make it possible to neutralise asbestos and use it as a harmless additive to ceramic, porcelain or construction products. Every effort should be made to ensure that these technologies are widely used, in particular in mass production (e.g. brick or cement production).

Furthermore, lessons should be drawn from the current issues related to asbestos tackled by developing countries. These
Podczas pożaru, w którym palą się elementy budowlane zawierające azbest, wszystkim osobom znajdującym się w odległości do 300 metrów wokół pożaru zaleca się stosowanie środków ochrony indywidualnej. Strażacy jako osoby będące najbliżej zagrożenia $[102,108]$ bezwzględnie powinni używać aparatów oddechowych w celu uniknięcia wdychania pyłów zawierających azbest. Większość wyposażenia ochronnego używanego przez strażaków eliminuje ekspozycję na włókna, ale $w$ drugorzędnych etapach prowadzenia działań ratowniczo-gaśniczych strażacy mogą zdejmować sprzęt ochronny dla większego komfortu pracy i nie zdawać sobie sprawy z obecności wysokich poziomów włókien azbestu w powietrzu.

Pomocne w takich przypadkach może okazać się monitorowanie uwolnienia się pyłów azbestowych lub produktów rozkładu termicznego, poprzez zastosowanie modelowania numerycznego w postaci dyspersji takich zanieczyszczeń w atmosferze. Jednakże należy przy tym uwzględnić poziom tła [102, 109, 110]. Wykorzystanie możliwości, jakie daje modelowanie numeryczne, może być również przydatne osobom odpowiedzialnym za kierowanie daną akcją ratowniczą [111]. Ponadto dobre praktyki pracy wskazują, że rozpylanie wody na gruzach podczas rozbiórki budynków lub po zawaleniu się budynku jest wskazane w celu utrzymania poziomu pyłów - w tym pyłu azbestu - na dole. Jednakże przy zdarzeniu tak dużym, jak zawalenie się wież WTC, praktyka ta nie była możliwa [112].

\section{Podsumowanie i wnioski}

Azbest i wyroby go zawierające przeszły trudną drogę - od dużego zainteresowania i powszechnego stosowania, aż do wprowadzonych ograniczeń w produkcji i użytkowaniu. Wyroby azbestowe posiadają unikalne właściwości, ale również są źródtem problemów przy ich unieszkodliwianiu. Utylizacja i przetwarzanie azbestu to trudny proces. Eliminując wyroby azbestowe, należy uważać, by nie spowodowało to jeszcze większych problemów dla ludzi i środowiska niż samo ich stosowanie.

Należy prowadzić ciągłe prace zmierzające do optymalizacji i przyspieszenia degradacji i unieszkodliwiania wyrobów azbestowych, a także dążyć do zdobycia i zarezerwowania przez nasz kraj odpowiednio wysokich środków pozwalających na usunięcie szkodliwych materiałów z gospodarstw domowych, instalacji ciepłowniczych (czyli z codziennego użytkowania) w założonych w „Programie usuwania azbestu” terminach.

Wprawdzie opracowano liczne technologie unieszkodliwiania wyrobów azbestowych, ale niejednokrotnie są to technologie w małej skali, których nie da się lub nie opłaca się przekształcać w technologie przemysłowe. Inną wadą opracowanych technologii jest to, że materiały używane do przetwarzania i unieszkodliwiania azbestu (np. fluor i jego związki) dla środowiska są bardziej szkodliwe niż sam unieszkodliwiany minerał. Z drugiej jednak strony istnieją również technologie, które pozwalają na unieszkodliwianie azbestu i dodawanie jego nieszkodliwej wersji do wyrobów ceramicznych, porcelanowych czy budowlanych. Należałoby dołożyć wszelkich starań, aby technologie te były powszechnie stosowane w szczególności w produkcjach masowych (np. wyrób cegieł lub cementu). 
lessons should be put into practice when introducing new materials into the market, ensuring that the problems related to their processing and disposal are not repeated. With this in mind, it is necessary to take into account not only the very good properties of a given material and the possibility of its wide applications in various products, but also aspects related to the safety of use and disposal, as well as the costs and energy intensity of these processes.

There are many problems to be solved with regard to asbestos disposal techniques. These involve the large quantities of chemical reagents required and the volume of wastewater generated during asbestos processing. However, it should be stressed that measures to speed up asbestos neutralisation are a step in the right direction.

The issues of asbestos and asbestos products still remain one of the most pressing issues of waste management in Poland. In order to achieve the main objective of removing asbestos-containing products from Poland by the end of 2032, it is necessary to accelerate efforts related to removing and neutralising asbestos products. One of the conditions for the actual efficiency improvement in this field is for the municipalities to develop asbestos removal programmes and collect complete information on the quantity and distribution of these materials. The process of removing asbestos products is a complex, lengthy and costly task which involves cooperation between different levels of government administration, local government and public involvement.

The disposal of asbestos-containing products has social, economic and environmental benefits. The advantages of removing those substances include the minimisation of asbestos fibre emissions, along with increasing the health protection of residents as well as improving the aesthetics of buildings and their technical condition.

In addition, it is recommended to conduct social campaigns concerning the harmfulness of asbestos and safe methods of handling it. Such training, supplemented with the tactics of rescue and firefighting operations, should also be mandatory for all firefighters.

Considering the prevalence of asbestos, procedures for dealing with fires involving asbestos and asbestos products should be developed, for example in the form of additional provisions to the fire safety procedures.

\section{Literature / Literatura}

[1] Baza Azbestowa - Zestawienie statystyczne, [dok. elektr.] https:// www.bazaazbestowa.gov.pl/pl/usuwanie-azbestu/zestawienie-statystyczne, [dostęp 26.07.2019].

[2] Ross M., Langer A.M., Nord G.L., The mineral nature of asbestos, "Regul Toxicol Pharmacol" 2008, 52, 2008, 26-30.
Dodatkowo należałoby wyciągnąć wnioski z problemów, które obecnie $z$ azbestem mają kraje rozwijające się i uwzględnić je podczas wprowadzania na rynki nowych materiałów, tak aby historia z problematycznym ich przetwarzaniem i unieszkodliwianiem się nie powtórzyła. W tej kwestii należy brać od uwagę nie tylko bardzo dobre właściwości danego materiału i możliwość szerokiego stosowania go w różnych wyrobach, ale również aspekty związane $z$ bezpieczeństwem użytkowania i unieszkodliwiania, a także kosztów i energochłonnością tych procesów.

Na rozwiązanie czeka wiele problemów związanych z opracowanymi lub opracowywanymi obecnie metodami unieszkodliwiania azbestu i wyrobów azbestowych. Wśród nich na uwagę zasługuje m.in.: stosowanie dużej ilości odczynników chemicznych, ścieki powstające podczas przetwarzania azbestu. Niemniej podkreślić należy, że działania mające na celu przyspieszenie neutralizacji azbestu idą $w$ dobrą stronę.

Rozwiązanie problemu azbestu i wyrobów azbestowych cały czas stanowi jedną z istotnych kwestii gospodarowania odpadami w Polsce. W celu osiągnięcia głównego założenia - usunięcia do końca 2032 roku wyrobów zawierających azbest z terenu Polski - należy przede wszystkim przyspieszyć prace związane z usuwaniem i unieszkodliwianiem wyrobów azbestowych. Jednym z warunków skutecznego zwiększenia efektywności na tym polu jest opracowanie przez gminy programów usuwania azbestu i zgromadzenie pełnych informacji na temat ilości i rozmieszczenia tych materiałów. Proces usuwania wyrobów azbestowych jest zadaniem złożonym, długotrwałym, kosztownym, a także wymagającym współpracy pomiędzy poszczególnymi szczeblami administracji rządowej, samorządowej oraz zaangażowania społeczeństwa.

Usunięcie z użytkowania wyrobów zawierających azbest niesie korzyści społeczne, ekonomiczne i ekologiczne. Wśród zalet należy przede wszystkim wymienić minimalizację emisji włókien azbestu, a tym samym zwiększenie ochrony zdrowia mieszkańców, a także poprawę estetyki obiektów budowlanych i ich stanu technicznego.

Dodatkowo rekomenduje się prowadzenie kampanii społecznych dotyczących szkodliwości azbestu i bezpiecznych metod postępowania z nim. Tego typu szkolenia, rozszerzone o taktykę prowadzenia działań ratowniczo-gaśniczych, powinni również obowiązkowo przechodzić strażacy.

Ze względu na powszechność występowania azbestu należałoby opracować procedury postępowania związane z wystąpieniem pożarów z udziałem azbestu i wyrobów azbestowych, np. w formie dodatkowych zapisów do procedur postępowania podczas pożarów.

[3] Iwaszko J., Asbestos-cement panels - microstructural investigations of asbestos fibres, "Prace Naukowe Akademii im Jana Długosza w Częstochowie Technika, Informatyka, Inżynieria Bezpieczeństwa" 2016, 4, 215-224.

[4] Witek J., Kusiorowski R., Neutralization of cement-asbestos waste by melting in an arc-resistance furnace, „Waste Management” 2017, 69, 336-345. 
[5] Kusiorowski R., Zaremba T., Piotrowski J., The potential use of cement-asbestos waste in the ceramic masses destined for sintered wall clay brick manufacture, "Ceramics International" 2014, 40, 11995-12002.

[6] Bandli B.R., Gunter M.E., A Review of Scientific Literature Examining the Mining History, Geology, Mineralogy, and Amphibole Asbestos Health Effects of the Rainy Creek Igneous Complex, Libby, Montana, USA, „Inhalation Toxicology" 2006, 18, 949-962, https://doi. org/10.1080/08958370600834982.

[7] Skinner H.C.W., Mineralogy of Asbestos Minerals, "Indoor and Built Environment" 2003, 12, 385-389.

[8] Maciołek Z., Zielińska A., Domarecki T., Oddziaływanie azbestu na środowisko przyrodnicze i organizm człowieka, „Journal of Ecology and Health" 2012, R.16, 3, 112-119

[9] Iwaszko J., Zawada A., Przerada I., Lubas M., Structural and microstructural aspects of asbestos-cement waste vitrification, "Spectrochim Acta A Mol Biomol Spectrosc" 2018, 195, 95-102.

[10] Pfau J.C., Immunotoxicity of asbestos, "Current Opinion in Toxicology" 2018, 10, 1-7.

[11] Zaremba T., Krząkała A., Piotrowski J., Garczorz D., Zastosowanie azbestu chryzotylowego jako surowca do produkcji wyrobów ceramicznych o spieczonym czerepie, "Materiały cermiczne” 2010, 62, 149-155.

[12] Oury T.D., Sporn T.A., Roggli V.L., Erratum to: Pathology of AsbestosAssociated Diseases, Third Edition, Pathology of Asbestos-Associated Diseases, w: T.D. Oury, T.A. Sporn, V.L. Roggli (red.), Springer Berlin Heidelberg, Berlin, Heidelberg 2016.

[13] Kuczumow A., Nowak J., Azbest - właściwości, utylizacja: zintegrowany system zarządzania unieszkodliwianiem azbestu w ujęciu systemowym, Towarzystwo Naukowe Organizacji i Kierownictwa "Dom Organizatora", Toruń 2013

[14] Bujak-Pietrek S., Szadkowska-Stańczyk I., Narażenie na działanie respirabilnych włókien azbestu podczas różnych etapów prac związanych z usuwanie, materiałów azbestowych, „Medycyna Pracy” 2012, 63, 191-198.

[15] Kusiorowski R., Zaremba T., Gerle A., Study on the thermal decomposition of crocidolite asbestos, „Journal of Thermal Analysis and Calorimetry" 2015, 120, 1585-1595.

[16] Brückner B., de Sagastuy J-R.B., Azbest, Wyd. Komitet Starszych Inspektorów Pracy (SLIC), 2006.

[17] Bojar E., Zintegrowany system zarządzania unieszkodliwianiem azbestu na składowiskach podziemnych $w$ aspekcie zrównoważonego rozwoju Polski Wschodniej, Towarzystwo Naukowe Organizacji i Kierownictwa - Stowarzyszenie Wyższej Użyteczności „Dom Organizatora", Toruń 2014

[18] Pyssa J., Rokita G.M., Azbest - występowanie, wykorzystanie i sposób postępowania z odpadami azbestowymi, "Gospodarka Surowcami Mineralnymi" 2007, 23, 49-61.

[19] Świątkowska B., Prawne aspekty ochrony zdrowia pracowników przed azbestem w Polsce w świetle unijnych ram prawnych, "Medycyna Pracy” 2013, 64, 689-697, https://doi.org/10.13075/mp.5893.2013.0057

[20] Gibbons W., The Exploitation and Environmental Legacy of Amphibole Asbestos: A Late 20th Century Overview, „Environmental Geochemistry and Health" 1998, 20, 1998, 213-230.

[21] Jawecki B., Programowanie usuwania azbestu na szczeblu lokalnym - propozycja wytycznych. Część 1, „Infrastruktura i ekologia terenów wiejskich" 2008, 9, 73-83.

[22] Obmiński A., Odpady azbestowe, składowanie, neutralizacja, zagrożenia, Materiały Szkoły Gospodarki Odpadami, Sympozja i Konferencje, 2000, 207-217.

[23] Więcek E., Azbest - narażenie i skutki zdrowotne, „Bezpieczeństwo Pracy" 2004, 2, 2-6
[24] Wójcik M., Asbestos in automotive waste. Contemporary recycling methods of waste from automotive industry, „AUTOBUSY - Technika, Eksploatacja, Systemy Transportowe" 2018, 19, 2018, 27-32.

[25] Szeszenia-Dąbrowska N., Azbest a zdrowie człowieka, Materiał dydaktyczny na kurs specjalistyczny, Bezpieczne postępowanie z azbestem i materiałami zawierającymi azbest, AGH, Kraków 2003.

[26] Zaremba T., Kusiorowski R., Możliwości wykorzystania eternitu w przemyśle ceramicznym, „Materiały cermiczne” 2011, 63, 294-300.

[27] Iwaszko J., Przerada I., Zawada A., Microstructural aspects of high -energy milling of asbestos-cement materials, "Materiały cermiczne" 2017, 69, 84-89.

[28] Sąkol G., Muszyńska-Graca M., Usuwanie płyt azbestowo-cementowych a narażenie zawodowe $i$ środowiskowe na azbest, "Medycyna Środowiskowa - Environmental Medicine" 2017, 20, 21-35.

[29] Ustawa z dnia 19 czerwca 1997 r. o zakazie stosowania wyrobów zawierających azbest (Dz.U. Nr 101, poz. 628).

[30] Urbaniak W., Historia azbestu - od euforii do zakazu, [dok. elektr.] https: //portalkomunalny.pl/historia-azbestu-od-euforii-zakazu-314159/2/ [dostęp: 3.12.2018].

[31] Dyrektywa Rady 85/610/EWG z dnia 20 grudnia 1985 r. zmieniająca dyrektywę 76/769/EWG w sprawie zbliżenia przepisów ustawowych, wykonawczych i administracyjnych Państw Członkowskich odnoszących się do ograniczeń we wprowadzaniu do obrotu i stosowaniu niektórych substancji i preparatów niebezpiecznych (Dz.Urz. WE L 375 z 31 grudnia 1985).

[32] Dyrektywa Komisji 91/659/EWG z dnia 3 grudnia 1991 r. dostosowująca do postępu załącznik I do Dyrektywy Rady 76/769/EWG w sprawie zbliżenia przepisów ustawowych, wykonawczych i administracyjnych Państw Członkowskich odnoszących się do ograniczeń we wprowadzaniu do obrotu i stosowaniu niektórych substancji i preparatów niebezpiecznych (Dz.Urz. WE L 363 z 31 grudnia 1991).

[33] Dyrektywa Komisji 1999/77/WE z 26 lipca 1999 r. w sprawie zbliżenia przepisów ustawowych, wykonawczych i administracyjnych państw członkowskich odnoszących się do ograniczeń we wprowadzaniu do obrotu i stosowaniu niektórych substancji i preparatów niebezpiecznych (Dz. Urz. WE L 207 z 6 sierpnia 1999 r., s. 18).

[34] Rozporządzenie (WE) nr 1907/2006 Parlamentu Europejskiego i Rady z dnia 18 grudnia 2006 r. w sprawie rejestracji, oceny, udzielania zezwoleń i stosowanych ograniczeń w zakresie chemikaliów (REACH) i utworzenia Europejskiej Agencji Chemikaliów, zmieniające dyrektywę 1999/45/WE oraz uchylające rozporządzenie Rady (EWG) nr 793/93 i rozporządzenie Komisji (WE) nr 1488/94, jak również dyrektywę Rady 76/769/EWG i dyrektywy Komisji 91/155/EWG, 93/67/EWG, 93/105/WE i 2000/21/WE (Dz.Urz. WE L 396 z 30 grudnia 2006 oraz sprostowanie w Dz.Urz. WE L 136 z 29 maja 2007 z późn. zm.)

[35] Dyrektywa Rady 87/217/EWG z dnia 19 marca 1987 r. w sprawie ograniczenia zanieczyszczenia środowiska azbestem i zapobiegania temu zanieczyszczeniu (Dz.Urz. WE L 85 z 28 marca 1987, z późn. zm.).

[36] Dyrektywa Rady 91/689/EWG z dnia 12 grudnia 1991 r. w sprawie odpadów niebezpiecznych (Dz.Urz. WE L 377 z 21 grudnia 1991 z późn. zm.).

[37] Dyrektywa Rady 94/31/WE z dnia 27 czerwca 1994 r. zmieniająca dyrektywę 91/689/EWG w sprawie odpadów niebezpiecznych (Dz. Urz. UE L168/28 z dnia 2 lipca 1994).

[38] Dyrektywa Parlamentu Europejskiego i Rady 2008/98/WE z dnia 19 listopada 2008 r. w sprawie odpadów oraz uchylająca niektóre dyrektywy (Dz.Urz. UE L 312 z 22 listopada 2008).

[39] Rozporządzenie Ministra Środowiska z dnia 27 września $2001 \mathrm{r}$. w sprawie katalogu odpadów (Dz. U. Nr 112, poz. 1206)

[40] Chronology of Asbestos Bans and Restrictions. http://ibasecretariat. org/chron_ban_list.php [dostęp: 22.03.2019]. 
[41] Ramos-Bonilla J.P., Cely-García M.F., Giraldo M., An asbestos contaminated town in the vicinity of an asbestos-cement facility: The case study of Sibaté, Colombia, „Environmental Research” 2019, 176, 108464.

[42] Park S-H. Types and Health Hazards of Fibrous Materials Used as Asbestos Substitutes, „Safety and Health at Work” 2018, 9, 360-364.

[43] Graphics Page Charts Row 1, http://ibasecretariat.org/graphics_ page_row2.php?n=5\#mit1_start [dostęp: 3.12.2018].

[44] LaDou J., Castleman B., Frank A., The case for a global ban on asbestos, „Environ Health Perspect” 2010, 118, 897-901.

[45] Program Oczyszczania Kraju z Azbestu 2009-2032, uchwała Rady Ministrów Rzeczpospolitej Polskiej nr 122/2009 z dnia 14 lipca 2009 r., zmieniona uchwałą Rady Ministrów nr 39/2010 z dnia 15 marca 2010 r., M.P. $2010 \mathrm{Nr} 33$ poz. 481.

[46] Terazono A., Moriguchi Y., Sakai S., Takatsuki H., Environmental impact assessment of sprayed-on asbestos in buildings, „J Mater Cycles Waste Manag" 2000, 2, 80-88.

[47] Yu I.J., Yoo C.Y., Chung Y.H., Asbestos exposure among Seoul metropolitan subway workers during renovation of subway air-conditioning systems, „Environment International” 2004, 29, 931-934.

[48] Subramanian V., Madhavan N., Asbestos problem in India, Lung Cancer 49 Suppl 1, 2005, 9-12.

[49] Anastasiadou K., Gidarakos E., Toxicity evaluation for the broad area of the asbestos mine of northern Greece, „J Hazard Mater" 2007, 139,9-18, https://doi.org/10.1016/j.jhazmat.2006.06.031.

[50] Dyczek J., Szkodliwe oddziaływanie azbestu na zdrowie ludzi, w: Bezpieczne postępowanie $z$ azbestem i materiałami zawierającymi azbest: Szkoła "Azbest - Bezpieczne Postępowanie", Dyczek J. (red.), 20-21 września 2007, AGH Kraków. Akapit, Kraków, 27-44.

[51] Viani A., Gualtieri A.F., Recycling the product of thermal transformation of cement-asbestos for the preparation of calcium sulfoaluminate clinker, J Hazard Mater" 2013, 260, 813-818, https://doi.org/10.1016/j.jhazmat.2013.06.020

[52] Gualtieri A.F., Cavenati C., Zanatto I., The transformation sequence of cement-asbestos slates up to 1200 degrees $C$ and safe recycling of the reaction product in stoneware tile mixtures. "J Hazard Mater" 2008, 152, 563-570, https://doi.org/10.1016/j.jhazmat.2007.07.037.

[53] Gualtieri A., Tartaglia A., Thermal decomposition of asbestos and recycling in traditional ceramics, "Journal of the European Ceramic Society" 2000, 20, 1409-1418.

[54] Malinowski M., Kidon J., Usuwanie wyrobów zawierających azbest z obszarów wiejskich. „Infrastruktura i Ekologia Terenów Wiejskich” 2015, 1, 109-119.

[55] Kotela I., Bednarenko M., Wilk-Frańczuk M., The effects of environmental exposure to asbestos dust on health, „Prz Lek” 2010, 67, 107-109.

[56] Hagemeyer O., Otten H., Kraus T., Asbestos consumption, asbestos exposure and asbestos-related occupational diseases in Germany, "Int Arch Occup Environ Health" 2006, 79, 613-620.

[57] Kusiorowski R., Zaremba T., Piotrowski J., Podwórny J., Utilisation of cement-asbestos wastes by thermal treatment and the potential possibility use of obtained product for the clinker bricks manufacture, "J Mater Sci” 2015, 50, 6757-6767, https://doi.org/10.1007/s10853-015-9231-6.

[58] Wilczyńska U., Szeszenia-Dąbrowska N., Występowanie pylicy azbestowej w Polsce, "Medycyna Pracy” 2002, 53, 375-379.

[59] Pepłońska B., Szeszenia-Dąbrowska N., Szymczak W., Sytuacja epidemiologiczna w zakresie chorób zawodowych w Polsce w roku 2002, Medycyna Pracy 2003, 54, 311-318.

[60] Szeszenia-Dąbrowska N., Wilczyńska U., Szymczak W., Pepłońska B., Choroby zawodowe stwierdzone w Polsce w 2003 r., "Medycyna Pracy" 2004, 55, 299-306.

[61] Szeszenia-Dąbrowska N., Wilczyńska U., Szymczak W., Choroby zawodowe stwierdzone w Polsce w 2004 r., „Medycyna Pracy” 2005, 56, 275-284.
[62] Wilczyńska U., Szeszenia-Dąbrowska N., Szymczak W., Choroby zawodowe stwierdzone w Polsce w 2005 r., „Medycyna Pracy” 2006, 57, 225-234.

[63] Wilczyńska U., Szeszenia-Dąbrowska N., Szymczak W., Choroby zawodowe stwierdzone w Polsce w 2006 r., „Medycyna Pracy” 2007, 58, 193-203.

[64] Wilczyńska U., Szeszenia-Dąbrowska N., Szymczak W., Choroby zawodowe stwierdzone w Polsce w 2007 r., „Medycyna Pracy"2008, 59, 113-122.

[65] Wilczyńska U., Szeszenia-Dąbrowska N., Szymczak W., Choroby zawodowe stwierdzone w Polsce w 2008 r., „Medycyna Pracy” 2009, 60, 167-178.

[66] Wilczyńska U., Szeszenia-Dąbrowska N., Sobala W., Choroby zawodowe stwierdzone w Polsce w 2009 r., "Medycyna Pracy" 2010, 61, 369-379.

[67] Wilczyńska U., Szeszenia-Dąbrowska N., Sobala W., Drożdż D., Choroby zawodowe stwierdzone w Polsce w 2010 r., "Medycyna Pracy” $2011,62,347-357$

[68] Szeszenia-Dąbrowska N., Wilczyńska U., Sobala W., Choroby zawodowe w Polsce w 2011 roku, Oficyna Wydawnicza MA, Łódź 2012.

[69] Wilczyńska U., Sobala W., Szeszenia-Dąbrowska N., Choroby zawodowe stwierdzone w Polsce w 2012 r., "Medycyna Pracy” 2013, 64, 217-326.

[70] Szeszenia-Dąbrowska N., Wilczyńska U., Sobala W., Choroby zawodowe stwierdzone w Polsce w 2013 r., „Medycyna Pracy” 2014, 65, 463-472.

[71] Szeszenia-Dąbrowska N., Wilczyńska U., Choroby zawodowe stwierdzone w Polsce w 2014 r., „Medycyna Pracy”2016, 67, 327-335.

[72] Świątkowska B., Hanke W., Choroby zawodowe w Polsce w 2016 roku, „Medycyna Pracy" 2018, 69, 643-650.

[73] Rezolucja Sejmu Rzeczypospolitej Polskiej z dnia 19 czerwca 1997 r. w sprawie programu wycofywania azbestu z gospodarki M.P.97.38.373, https://doi.org/10.1021/ie9702744.

[74] Rozporządzenie Ministra Gospodarki z dnia 13 grudnia 2010 r. w sprawie wymagań w zakresie wykorzystywania wyrobów zawierających azbest oraz wykorzystywania i oczyszczania instalacji lub urządzeń, w których były lub są wykorzystywane wyroby zawierające azbest (Dz.U. 2011 Nr 8 poz. 31).

[75] Sugama T., Sabatini R., Petrakis L., Decomposition of Chrysotile Asbestos by Fluorosulfonic Acid, „Ind Eng Chem Res” 1998, 37, 79-88.

[76] Yanagisawa K., Kozawa T., Onda A., Kanazawa M., A novel decomposition technique of friable asbestos by CHCIF2-decomposed acidic gas, „Journal of Hazardous Materials" 2009, 163, 593-599.

[77] Rozalen M., Huertas F.J., Comparative effect of chrysotile leaching in nitric, sulfuric and oxalic acids at room temperature, "Chemical Geology” 2013, 352, 134-142, https://doi.org/10.1016/j.chemgeo.2013.06.004.

[78] Domka L., Domka L., Kozak M., Utilisation of asbestos wastes, „Fizyko-chemiczne Problemy Mineralurgii" 2001, 35, 83-90.

[79] Martino E., Prandi L., Fenoglio I., Soil fungal hyphae bind and attack asbestos fibers, „Angew Chem Int Ed Engl” 2003, 42, m, 2003, 219-222.

[80] Plescia P, Gizzi D,, Benedetti S., Mechanochemical treatment to recycling asbestos-containing waste, "Waste Manag” 2003, 23, 209-218, https://doi.org/10.1016/S0956-053X(02)00156-3.

[81] Colangelo F., Cioffi R., Lavorgna M., Treatment and recycling of asbestoscement containing waste, „J Hazard Mater" 2011, 195,391-397, https:// doi.org/10.1016/j.jhazmat.2011.08.057.

[82] Zaremba T., Krząkała A., Piotrowski J., Garczorz D., Study on the thermal decomposition of chrysotile asbestos, „Journal of Thermal Analysis and Calorimetry" 2010, 101, 479-485.

[83] Kusiorowski R., Zaremba T., Piotrowski J., Adamek J., Thermal decomposition of different types of asbestos, „Journal of Thermal Analysis and Calorimetry" 2012, 109, 693-704.

[84] Iwaszko J., Making asbestos-cement products safe using heat treatment, Case Studies in Construction Materials 10, 2019, e00221. 
[85] Kusiorowski R., Zaremba T., Piotrowski J., Gerle A, Thermal decomposition of asbestos-containing materials, „J Therm Anal Calorim” 2013, 113, 179-188, https://doi.org/1007/s10973-012-2222-9.

[86] Leonelli C., Veronesi P., Boccaccini D.N., Microwave thermal inertisation of asbestos containing waste and its recycling in traditional ceramics, „J Hazard Mater" 2006, 135, 149-155, https://doi.org/10.1016/j. jhazmat.2005.11.035.

[87] Corradi A., Siligardi C., Veronesi P., Microwave irradiation of asbestos containing materials, „Material Research Innovations” 2004, 8, 65-67.

[88] Favero-Longo S.E., Turci F., Tomatis M., Chrysotile asbestos is progressively converted into a non-fibrous amorphous material by the chelating action of lichen metabolites, „J Environ Monit” 2005, 7, 764-766, https:// doi.org/10.1039/b507569f.

[89] Spasiano D., Pirozzi F., Treatments of asbestos containing wastes, „Journal of Environmental Management" 2017, 204, 82-91, https:// doi.org/10.1016/j.jenvman.2017.08.038.

[90] Dyczek J., Eksploatacja i usuwanie wyrobów zawierających azbest, "Materiały Budowlane" 2006, 11, 46-48.

[91] Dyczek J., Transport i składowanie odpadów niebezpiecznych zawierających azbest, w: Bezpieczne postępowanie z azbestem i materiałami zawierającymi azbest, Dyczek J. (red.) Akapit, Kraków 2007, 7-27

[92] Koumantakis E., Kalliopi A., Dimitrios K., Gidarakos E., Asbestos pollution in an inactive mine: determination of asbestos fibers in the deposit tailings and water, „J Hazard Mater” 2009, 167, 1080-1088.

[93] Pawluk K., Nowe metody unieszkodliwiania odpadów budowlanych zawierających azbest, Prace Naukowo-Przeglądowe Przegląd Naukowy Inżynieria i Kształtowanie Środowiska, 49, 2010, 38-47, https://doi. org/10.1016/j.jhazmat.2009.01.102.

[94] Linert S., Utylizacja azbestu w technologii MTT - w aspekcie badań $i$ analiz laboratoryjnych, Włocławek, 2008, [dok. elektr.] http://www. eko-proj-edu.pl/pliki/Inzynieria/Utylizacja\%20azbestu\%20w\%20 technologii\%20MTT\%20\%E2\%80\%93\%20w\%20oparciu\%200\%20 przeprowadzone\%20badania.pdf [dostęp: 15.05.2019]

[95] Yoshikawa N., Kashimura K., Hashiguchi M., Detoxification mechanism of asbestos materials by microwave treatment, "Journal of Hazardous Materials" 2015, 284, 201-206, https://doi.org/10.1016/j. jhazmat.2014.09.030.

[96] Boccaccini D.N., Leonelli C., Rivasi M.R., Recycling of microwave inertised asbestos containing waste in refractory materials, „Journal of the European Ceramic Society" 2007, 27, 1855-1858, https://doi. org/10.1016/j.jeurceramsoc.2006.05.003.

[97] Asbestos and fire damaged buildings, [dok. elektr.] http://www.deir. qld.gov.au/asbestos/resources/pdfs/asbestos-fire-damaged-buildings.pdf [dostęp: 15.05.2019]

DOROTA SZUŁCZYŃSKA, PH.D. - a graduate of the Faculty of Materials Science at the Warsaw University of Technology, where in 2012 she defended her Ph.D. dissertation entitled Characterisation of the structure of ceramic archaeological objects. At CNBOP-PIB she deals with broadly understood security issues. Her main research interests concern flood protection, logistics of rescue and firefighting operations, thermal properties and flame resistance of polymeric materials and composites as well as recycling. She is an author of over 30 publications of national and international scale, as well as presentations at numerous conferences and symposia.
[98] Kullberg C., Andersson T., Gustavsson P., Cancer incidence in firefighters in sweden - preliminary findings from an updated cohort study, $\mathrm{w}$ : Oral Presentation. BMJ Publishing Group Ltd, 2017, A99.2-A100.

[99] Landrigan P.J., Lioy P.J., Thurston G., Health and environmental consequences of the world trade center disaster, Environ Health Perspect 112, 2004, 731-739, https://doi.org/10.1289/ehp.6702.

[100] Rom W.N., Weiden M., Garcia R., Acute Eosinophilic Pneumonia in a New York City Firefighter Exposed to World Trade Center Dust, "Am J Respir Crit Care Med" 2002, 166, 797-800, 797-800, https://doi. org/10.1164/rccm.200206-5760C.

[101] Landrigan P.J., Health consequences of the 11 September 2001 attacks, „Environmental Health Perspectives” 2001, 109, 514-515, https://doi.org/10.1289/ehp.109-a514.

[102] Saunders P., Smith K.R., The public health significance of asbestos exposures from large scale fires, Chemical Hazards and Poisons Division, Health Protection Agency, Didcot 2007.

[103] Nolan R.P., Ross M., Nord G.L., Risk assessment for asbestos-related cancer from the 9/11 attack on the World Trade Center, "J Occup Environ Med" 2005, 47, 2005, 817-825, https://doi.org/10.1097/01. jom.0000167273.17109.6d.

[104] Luz C., Firefighter Findings: Biomonitoring Rescue Workers after WTC Attacks, „Environmental Health Perspectives” 2003, 111, 896, https://doi.org/10.1289/ehp.111-a896a.

[105] Lewis N.J., Curtis M.F., Occupational health and hygiene following a fire in a warehouse with an asbestos cement roof, "J Soc Occup Med" $1990,40,53-54$.

[106] Bridgman S., Community health risk assessment after a fire with asbestos containing fallout, "Journal of Epidemiology \& Community Health" 2001, 55, 921-927, https://doi.org/10.1136/jech.55.12.921.

[107] Asbestos, 9/11 and the World Trade Center. https://www.asbestos. com/world-trade-center/ [dostęp: 8.05.2019].

[108] Bridgman S.A. Acute health effects of a fire associated with asbestoscontaining fallout, J „Public Health Med” 2000, 22, 400-405, https:// doi.org/10.1093/pubmed/22.3.400.

[109] Royal Commission on Matters of Health and Safety Arising from the Use of Asbestos in Ontario, Dupré J.S., Report of the Royal Commission on Matters of Health and Safety Arising from the Use of Asbestos in Ontario, Ontario Ministry of the Attorney General, Toronto 1984.

[110] Bignon J., Mineral fibres in the non-occupational environment, „IARC Sci Publ" 1989, 3-29.

[111] Porowski R., Awaryjne uwolnienia substancji palnych do środowiska, Wyd. SGSP, 2017.

[112] Beckett W.S., A New York City Firefighter: Overwhelmed by World Trade Center Dust, „Am J Respir Crit Care Med" 2002, 166, 785-786, https://doi.org/10.1164/rccm.2208001.

DR INŻ. DOROTA SZUŁCZYŃSKA - absolwentka Wydziału Inżynierii Materiałowej Politechniki Warszawskiej, gdzie w 2012 r. obroniła rozprawę doktorską pt.: Charakterystyka struktury ceramicznych obiektów archeologicznych. W CNBOP-PIB zajmuje się szeroko rozumianą tematyką bezpieczeństwa. Wśród głównych tematów znajdują się: ochrona przeciwpowodziowa, logistyka prowadzenia akcji ratowniczo-gaśniczych, właściwości termiczne i odporność na działanie płomienia materiałów polimerowych oraz kompozytów polimerowych oraz recykling materiałów. Wyniki badań zostały opublikowane w ponad 30 publikacjach o zasięgu krajowym i międzynarodowym, a także były prezentowane na licznych konferencjach i sympozjach. 